\title{
Cytotoxic Agents in the Minor Alkaloid Groups of the Amaryllidaceae"
}

\author{
Authors \\ Jerald J. Nair, Johannes van Staden \\ Affiliation \\ Research Centre for Plant Growth and Development, \\ University of KwaZulu-Natal Pietermaritzburg, Scottsville, \\ South Africa \\ Key words \\ Amaryllidaceae, antiproliferative, cancer, cytotoxic, \\ isoquinoline alkaloid

$\begin{array}{ll}\text { received } & \text { December 12, } 2020 \\ \text { accepted after revision } & \text { February 16, 2021 } \\ \text { published online } & \text { March 11, 2021 }\end{array}$ \\ Bibliography \\ Planta Med 2021; 87: 916-936 \\ DOI $10.1055 / \mathrm{a}-1380-1888$ \\ ISSN 0032-0943 \\ (C) 2021. Thieme. All rights reserved. \\ Georg Thieme Verlag KG, Rüdigerstraße 14, \\ 70469 Stuttgart, Germany \\ Correspondence \\ Prof. Johannes van Staden \\ Research Centre for Plant Growth and Development, \\ School of Life Sciences, University of KwaZulu-Natal \\ Pietermaritzburg \\ Private Bag X01, 62 Carbis Road, 3209 Scottsville, \\ South Africa \\ Phone: + 27332605130 , Fax: + 27332605897 \\ rcpgd@ukzn.ac.za
}

$\bigoplus \begin{aligned} & \text { Supplementary material is available under } \\ & \text { https://doi.org/10.1055/a-1380-1888 }\end{aligned}$

\section{ABSTRACT}

Over 600 alkaloids have to date been identified in the plant family Amaryllidaceae. These have been arranged into as many as 15 different groups based on their characteristic structural features. The vast majority of studies on the biological properties of Amaryllidaceae alkaloids have probed their anticancer potential. While most efforts have focused on the major alkaloid groups, the volume and diversity afforded by the minor alkaloid groups have promoted their usefulness as targets for cancer cell line screening purposes. This survey is an in-depth review of such activities described for around 90 representatives from 10 minor alkaloid groups of the Amaryllidaceae. These have been evaluated against over 60 cell lines categorized into 18 different types of cancer. The montanine and cripowellin groups were identified as the most potent, with some in the latter demonstrating low nanomolar level antiproliferative activities. Despite their challenging molecular architectures, the minor alkaloid groups have allowed for facile adjustments to be made to their structures, thereby altering the size, geometry, and electronics of the targets available for structure-activity relationship studies. Nevertheless, it was seen with a regular frequency that the parent alkaloids were better cytotoxic agents than the corresponding semisynthetic derivatives. There has also been significant interest in how the minor alkaloid groups manifest their effects in cancer cells. Among the various targets and pathways in which they were seen to mediate, their ability to induce apoptosis in cancer cells is most appealing.

\section{Introduction}

Cancer is a leading cause of death, with only cardiovascular diseases estimated to have caused more deaths worldwide in 2018 [1]. The outlook is just as compelling, with the number of cases set to rise sharply from around 18 million in 2018 to about 30 million by 2040 [1]. There is also a serious concern for the strain cancer morbidity can have on healthcare resources [1]. Despite this bleak picture, the range of treatment options available today, such as chemotherapy, radiotherapy, immunotherapy, targeted therapy, hormone therapy, stem cell transplant, and surgery, has profoundly influenced relapse and cancer recovery [1]. However, most, if not all, patients will succumb to a chemotherapeutic form of intervention at some point in the disease [1]. Although the best-selling cancer drugs are either synthetic entities or monoclonal antibodies, natural product-based substances still constitute roughly $60 \%$ of the cancer drug market [2]. This has been demonstrated by standout examples such as taxol (from Taxus brevifolia Nutt.), vincristine (from Catharanthus roseus (L.) G. Don), campthothecin (from Camptotheca acuminata Decne.), and podophyllotoxin (from Podophyllum peltatum L.), which have experienced unprecedented levels of success on the clinic floor [2]. Given this

\# Dedicated to Professor Arnold Vlietinck on the occasion of his 80th birthday. 


\begin{tabular}{ll} 
ABBREVIATIONS \\
ATCC & American Type Culture Collection \\
CTM & Chinese Traditional Medicine \\
IC & inhibitory concentration \\
MDA & malondialdehyde \\
MDR & multidrug-resistant \\
MMP & mitochondrial membrane potential \\
MTD & minimum toxic dose \\
PAR & parental \\
ROS & reactive oxygen species \\
SAR & structure-activity relationship \\
SRB & sulphorhodamine B \\
& \\
\hline
\end{tabular}

fact, as well as their broad numerical basis and chemical diversity, interest in plants as a source of anticancer drugs has been unwavering [2].

The plant family Amaryllidaceae has likewise attracted considerable attention in the chemical, biological, and medical fields [3]. It is richly represented with nearly 1000 species that occur in pantropical regions [3]. Several of its members are known to be (or have been) used in traditional medicinal treatments for cancer [4]. Apart from its attractive floral attributes, the structurally-diverse isoquinoline alkaloid principles of the Amaryllidaceae are the features through which they have come to be recognized [3]. In addition to their interesting molecular architectures, these compounds also exhibit a significant array of biological properties, particularly as motorneuron and cancer therapeutic agents [3]. Following the commercialization of galanthamine (1) ( $\triangleright$ Fig. 1) as an Alzheimer's disease drug-the first of the Amaryllidaceae alkaloids to be granted FDA approval-there was a shift in focus toward the potential that could be realized for these compounds in the cancer arena [3]. Thus, over the past 2 decades, most of the biological studies of Amaryllidaceae alkaloids have centered on their cytotoxic properties [3].

The flagship representatives of the family in the cancer area are the phenanthridone alkaloids narciclasine (2) and pancratistatin (3) [5]. Although the initial description of each of these compounds was separated by a period of nearly $20 \mathrm{y}[6,7]$, it was the isolation of pancratistatin in 1984 that set the wheels in motion for cell line evaluations not only of phenanthridones but all the alkaloid groups of the Amaryllidaceae [5]. Narciclasine (2) was identified as one of the most potent natural product entities in the $\mathrm{NCI}$ 60 panel screen, with a mean $\mathrm{Gl}_{50}(0.016 \mu \mathrm{M})$ over 5 times better than that of pancratistatin (3) [5]. Valuable information then appeared on their safety, efficacy, and tolerability in a wide variety of in vitro and in vivo models of study [5]. This propelled both compounds into clinical trials where, by most accounts, they exceeded expectations, with only low aqueous solubility serving to mitigate their progress [5].

The other recognized cytotoxic agents of the Amaryllidaceae are found in its lycorane and crinane alkaloid groups [8]. Epitomized by lycorine (4) and haemanthamine (5), respectively, these compounds came to prominence in the 1970s due to their potent in vitro and in vivo effects against Rauscher leukemia [8]. The best activity observed for lycorine was against the $\mathrm{HL}-60$ promyelocytic leukemia cell line $\left(\mathrm{IC}_{50} 0.6 \mu \mathrm{M}\right)$, while that for haemanthamine was determined in HT-1080 fibrosarcoma cells (ED 50 $0.3 \mu \mathrm{g} / \mathrm{mL}$ ) [8]. Both alkaloids were also shown to be potent and selective inducers of apoptosis in various cancer cells [8]. They were also seen to incorporate tractable features that allowed for facile modifications to their structures, thus significantly enhancing the number of compounds available for screening purposes [8].

Lycorane and crinane alkaloids make up the major alkaloid groups of the Amaryllidaceae [9]. Due to their more limited distribution and diversity, all other alkaloids found in these plants represent the minor alkaloid groups [9]. These include the galanthamine and phenanthridone groups as well as others, namely the belladine (6), ismine (7), trisphaeridine (8), bicolorine (9), cherylline (10), tazettine (11), homolycorine (12), montanine (13), lycosinine (such as lycosinine B 14), augustamine (15) and cripowellin (such as cripowellin A 16) groups [9]. While much has been detailed about the cytotoxic effects of the major alkaloid groups of the Amaryllidaceae [8], except for its phenanthridones, comparatively little is understood about such properties for the minor alkaloid groups. With this as a backdrop, this survey takes an indepth look at the cancer cell line activities reported for representatives from this group, highlights the structural features which have a modulatory role, and decodes the various molecular mechanisms used to explain such action.

\section{The Belladine Group}

The central nitrogen atom of these compounds contains pendant benzyl and phenylethyl groups as in norbelladine (17), or it may be trisubstituted by the inclusion of a methyl group as in belladine (6) [3]. This group's key function lies with the diamine norbelladine (17), which has been shown to be the biogenetic precursor of the Amaryllidaceae alkaloids [3]. Two articles were found on the in vitro cancer cell line screening of belladine-type alkaloids $[10,11]$, while a further 3 focused on the mechanistic aspects of their cytotoxicity as discussed elsewhere in the text [12-14]. 4-O-Methylnorbelladine (18) and 11 other alkaloids were isolated from Galanthus trojanus A.P.Davis \& Özhatay [10]. Its activities were shown to be poor against both normal L6 mouse myoblasts and human oral epidermoid KB carcinoma cells $\left(\mathrm{IC}_{50} \mathrm{~s}>50 \mu \mathrm{g} / \mathrm{mL}\right)$ relative to podophyllotoxin $\left(\mathrm{IC}_{50} \mathrm{~s} 0.005\right.$ and $0.002 \mu \mathrm{g} / \mathrm{mL}$, respectively) [10]. However, the fact that 4-O-methylnorbelladine (18) exhibited negligible effects on the normal cell line in contrast to podophyllotoxin was in this instance noteworthy [10]. In the second study, Crinum scillifolium A.Chev. yielded 3 belladine structures that were identified as 4-O-methylnorbelladine (18), 4-O,Ndimethylnorbelladine (19), and 4-O,N-dimethylnorbelladine- $\mathrm{N}$ oxide (20) [11]. In the adjoining biological evaluation, negligible effects were observed for all 3 compounds (at $1 \mu \mathrm{M}$ ) on the HCT116 colon carcinoma cell line where cell viabilities were high (>90\%) [11]. However, there was some modulation in activity (75\% viability) for 4-O,N-dimethylnorbelladine-N-oxide (20) when its concentration was increased to $10 \mu \mathrm{M}[11]$. 


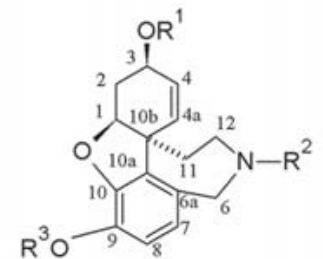

1. $\mathrm{R}^{1}=\mathrm{H}, \mathrm{R}^{2}=\mathrm{R}^{3}=\mathrm{CH}_{3}$ (Galanthamine) 30. $\mathrm{R}^{1}=\mathrm{R}^{2}=\mathrm{H}, \mathrm{R}^{3}=\mathrm{CH}_{3}$ (Norgalanthamine) 34. $\mathrm{R}^{1}=\mathrm{H}, \mathrm{R}^{2}=\mathrm{CHO}, \mathrm{R}^{3}=\mathrm{CH}_{3}$ ( $N$-Formylgalanthamine) 38. $\mathrm{R}^{1}=\mathrm{R}^{3}=\mathrm{H}, \mathrm{R}^{2}=\mathrm{CH}_{3}$ (Sanguinine) 39. $\mathrm{R}^{1}=\mathrm{R}^{2}=\mathrm{CH}_{3}, \mathrm{R}^{3}=\mathrm{H}$, (Chlidanthine)

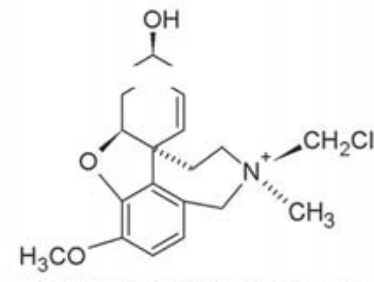

43. $\mathrm{N}$-Chloromethylgalanthamine

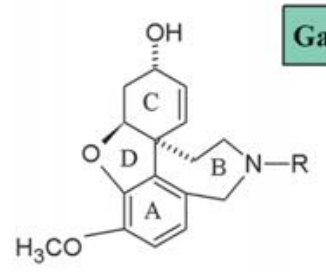

31. $\mathrm{R}=\mathrm{CH}_{3}$ (3-Epigalanthamine) 37. $\mathrm{R}=\mathrm{H}$ (3-Epinorgalanthamine)<smiles>COc1cccc2c1OC1CC(O)C=C[C@]21CC[N+](C)(C)Br</smiles>

40. Galathamine hydrobromide<smiles>COc1ccc2c3c1OC1CC(O)CC[C@@]31CC[N+](C)(CCl)C2</smiles>

44. $\mathrm{N}$-Chloromethyllycoramine

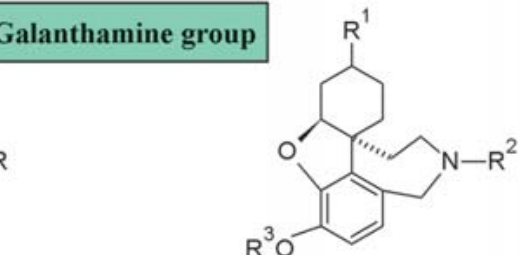

32. $\mathrm{R}^{1}=\beta-\mathrm{OH}, \mathrm{R}^{2}=\mathrm{R}^{3}=\mathrm{CH}_{3}$ (Lycoramine) 35. $\mathrm{R}^{1}=\mathrm{O}=\mathrm{R}^{2}=\mathrm{R}^{3}=\mathrm{CH}_{3}$ (Lycoraminone) 36. $\mathrm{R}^{1}=\beta-\mathrm{OH}, \mathrm{R}^{2}=\mathrm{H}, \mathrm{R}^{3}=\mathrm{CH}_{3}$ (Norlycoramine)

47. $\mathrm{R}^{1}=\beta-\mathrm{OH}, \mathrm{R}^{2}=\mathrm{CH}_{3}, \mathrm{R}^{3}=\mathrm{H}$ (9-O-Demethyllycoramine)<smiles>COc1cccc2c1OC1CC(O)C=C[C@]21CCN(C)C=O</smiles>

41. Galathamine- $N$-oxide<smiles>CCN(C)CCC12CC[C@@H](O)CC1Oc1c(O)cccc12</smiles>

45. 3-Epidihydrosanguinine<smiles>COc1ccc2c3c1OC1CC(=O)C=CC31CCN(C)C2</smiles>

33. Narwedine

- Fig. 1 Cytotoxic agents in the galanthamine, phenanthridone, lycorane and crinane alkaloid groups of the Amaryllidaceae.

\section{The Ismine Group}

The ismine group represents compounds wherein connectivity has been established between the 2 aryl rings, which would normally make up rings $A$ and $C$ of other alkaloids such as narciclasine (2), lycorine (4), and haemanthamine (5) [9]. The tetrasubstituted A-ring contains the methylenedioxy and hydroxymethyl groups, while the $\mathrm{C}$-ring possesses the $\mathrm{N}$-methyl group in the ortho position. Energy minimization of the ismine (7) ( $\vee$ Fig. 2) structure shows, as expected, the hydroxymethyl and $N$-methyl groups to be antipodal to each other [9]. In 2009, Zupko et al. carried out the first study to describe the cytotoxic effects for such compounds following the isolation of ismine (7) from Hymenocallis $x$ festalis (Worsley) Schmarse [15]. The effects of ismine (7) on HeLa 


\section{Belladine group}<smiles>[R]Oc1ccc(CN([R])CCc2ccc([R])cc2)cc1[R]</smiles>

6. $\mathrm{R}^{1}=\mathrm{R}^{2}=\mathrm{R}^{3}=\mathrm{R}^{4}=\mathrm{CH}_{3}$ (Belladine)

17. $R^{1}=R^{2}=R^{3}=R^{4}=H$ (Norbelladine)

18. $\mathrm{R}^{1}=\mathrm{R}^{2}=\mathrm{R}^{3}=\mathrm{H}, \mathrm{R}^{4}=\mathrm{CH}_{3}$ (4-O-Methylnorbelladine)

19. $\mathrm{R}^{1}=\mathrm{R}^{3}=\mathrm{H}, \mathrm{R}^{2}=\mathrm{R}^{4}=\mathrm{CH}_{3}$ (4-O,N-Dimethylnorbelladine)

86. $\mathrm{R}^{1}=\mathrm{R}^{2}=\mathrm{H}, \mathrm{R}^{3}=\mathrm{R}^{4}=\mathrm{CH}_{3}$ (Latisodine)

\section{Ismine group}

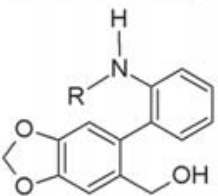

7. $\mathrm{R}=\mathrm{CH}_{3}$ (Ismine)

21. $\mathrm{R}=\mathrm{H}$ (Norismine)

83. $\mathrm{R}=\mathrm{HCO}(N$-Formylismine)<smiles>COc1ccc(CN(C)C(=O)CO)cc1O</smiles>

20. 4-O,N-Dimethylnorbelladine- $N$-oxide<smiles>COc1ccc(/C=N\CCc2ccc(O)cc2)cc1O</smiles>

84. Craugsodine<smiles>COC1=C/C(=C\NCCc2ccc(O)cc2)C=CC1=O</smiles>

85. Isocraugsodine
Trisphaeridine group

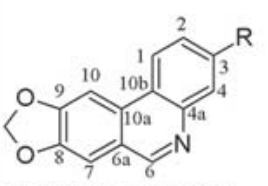

8. $\mathrm{R}=\mathrm{H}$ (Trisphaeridine)

87. $\mathrm{R}=\mathrm{OH}$

(3-Hydroxytrisphaeridine)<smiles>CO[C@H]1CCc2ncc3cc4c(cc3c2C1)OCO4</smiles>

22. 2-Methoxy-1,2,3,4-tetrahydrotrisphaeridine

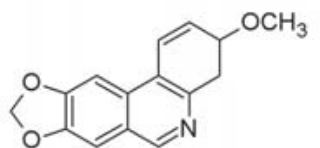

23. 3-Methoxy-3,4-dihydrotrisphaeridine<smiles>C[n+]1cc2cc3c(cc2c2ccccc21)OCO3</smiles>

9. Bicolorine
24. $\mathrm{R}^{1}=\mathrm{R}^{2}=\mathrm{H}$ (5,6-Dihydrobicolorine) 25. $\mathrm{R}^{1}=\mathrm{H}, \mathrm{R}^{2}=\mathrm{OH}$ (2-Hydroxy-5,6dihydrobicolorine)

26. $\mathrm{R}^{1}=\mathrm{R}^{2}=\mathrm{OH}$ (1,2-Dihydroxy-5,6dihydrobicolorine)

\section{Cherylline group}

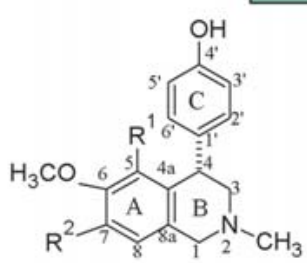

10. $\mathrm{R}^{1}=\mathrm{H}, \mathrm{R}^{2}=\mathrm{OH}$ (Cherylline) 27. $\mathrm{R}^{1}=\mathrm{OH}, \mathrm{R}^{2}=\mathrm{H}$ (Latifine)<smiles>[R20]Oc1ccc([C@H]2CN(C)Cc3cc(OC)c(OC)cc32)cc1[R]</smiles>

28. $\mathrm{R}^{1}=\mathrm{CH}_{3}, \mathrm{R}^{2}=\mathrm{R}^{3}=\mathrm{H}$

(Gigantelline)

29. $\mathrm{R}^{1}=\mathrm{H}, \mathrm{R}^{2}=\mathrm{CH}_{3}, \mathrm{R}^{3}=\mathrm{OH}$

(Gigantellinine)<smiles></smiles>

77. Zephycandidine A

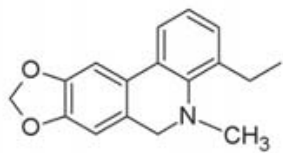

81. 4-Ethyl-5,6-Dihydrobicolorine

- Fig. 2 Cytotoxic agents in the belladine, ismine, trisphaeridine, bicolorine, cherylline, tazettine and homolycorine alkaloid groups of the Amaryllidaceae. 
cervical and MCF7 breast adenocarcinoma, as well as sensitive L5178 PAR and resistant L5178 MDR mouse lymphoma cells, were ascertained spectrophotometrically via the MTT stain [15]. However, the activities in all instances were poor as reflected by $I_{50} \mathrm{~S}$, which were $>30 \mu \mathrm{M}$ against HeLa and MCF7 and $>90 \mu \mathrm{M}$ against both L5178 cell lines (Table 1S, Supporting Information) [15]. In the same instance, doxorubicin exhibited a mean $\mathrm{IC}_{50}$ value of $0.51 \mu \mathrm{M}$ against the first 3 of these cells [15]. Other noteworthy aspects about the cytotoxicity of ismine (7) highlighted in this study will be discussed later in the text. Norismine (21), the N-demethylated variant of ismine (7), together with 6 other alkaloids, have been described in Pancratium maritimum L. [16]. It was subsequently screened for cytotoxic effects against the PC-3 prostate adenocarcinoma cell line, and its effect was poor, with the lowest cell viability of $65 \%$ determined at the highest tested concentration of $50 \mu \mathrm{M}[16]$.

\section{The Trisphaeridine Group}

This group comprises phenanthridine-related structures that have elaborated the biaryl ismine nucleus to forge the B-ring [9]. This transformation involves oxidation of the hydroxymethyl group to an aldehyde, $\mathrm{N}$-demethylation followed by B-ring cyclization to the imine product, as in trisphaeridine (8) [9]. Given the highly conjugated nature of its structure, trisphaeridine is a flat molecule [9]. In addition to ismine (7), the parent compound trisphaeridine (8) has also been described in Hymenocallis $x$ festalis and subjected to screening against the HeLa, MCF7, A431 (epidermoid carcinoma), L5178 PAR, and L5178 MDR cell lines (Table 1S, Supporting Information) [15]. However, activities for trisphaeridine (8), gauging by its $I C_{50}$ values, were all poor $(24.1,21.1,>30,20.3$, and $29.5 \mu \mathrm{M}$, respectively) relative to doxorubicin (mean $I C_{50}$ $0.42 \mu \mathrm{M}$ ) [15]. Fifteen alkaloids, including trisphaeridine (8), were isolated from Zephyranthes candida (Lindl.) Herb. collected in the Hubei province of China [17]. The cell line evaluation involved HL-60, K562 (myelogenous leukemia), A549 (lung carcinoma), HepG2 (hepatocellular carcinoma), and HT-29 (colon adenocarcinoma) cells [17]. After $48 \mathrm{~h}$ treatment, MTT staining was carried out to ascertain the extent to which proliferation had occurred [17]. Trisphaeridine (8) was seen to be a poor cytotoxic agent since its $\mathrm{IC}_{50}$ value in each case was $>40 \mu \mathrm{M}$ relative to taxol (mean $\mathrm{IC}_{50} 0.08 \mu \mathrm{M}$ ) [17].

A chemical investigation of the Chinese medicinal plant Lycoris radiata (L'Hér.) Herb. led to the isolation of 11 alkaloids, among which was the trisphaeridine-related structure 2-methoxy1,2,3,4-tetrahydrotrisphaeridine (22) [18]. In addition to shedding its C-ring's aromaticity, compound 22 also incorporates a methoxyl functionality at C-2 in this partially-saturated ring [18]. The ATCC cell lines used to establish the cytotoxic effects of compound 22 included A549 lung carcinoma and LoVo colon adenocarcinoma cells [18]. MTT staining indicated that neither cell line was susceptible to treatments with compound 22 , which exhibited $\mathrm{IC}_{50}$ values $>20 \mu \mathrm{M}$ in each case relative to doxorubicin (mean $\left.I_{50} 0.53 \mu \mathrm{M}\right)$ [18]. Despite these poor activities, the presence of lycorine (4) (mean IC $5013.5 \mu \mathrm{M}$ ) together with other cytotoxic alkaloids could corroborate the traditional usage of $L$. radiata as a cancer medicament [18]. Further studies of the genus Lycoris were in association with Lycoris longituba Y.C.Hsu \& G. J.Fan, a native of south-eastern China, with several functions in CTM [19]. Analysis of fresh bulb extracts led to the identification of 22 alkaloids, one of which was the planar, tricyclic compound trisphaeridine (8) [19]. The cytotoxicity component of the investigation used SH-SY5Y neuroblastoma cells that were exposed to trisphaeridine (at $6.25,12.5,25,50$, and $100 \mu \mathrm{M}$ ) as well as to the cell perturbation agents $\mathrm{H}_{2} \mathrm{O}_{2}(300 \mu \mathrm{M}), \mathrm{A} \beta_{25-35}(1 \mu \mathrm{M})$, or $\mathrm{CoCl}_{2}$ $(265 \mu \mathrm{M})$ [19]. Significant relief from $\mathrm{H}_{2} \mathrm{O}_{2^{-}}, \mathrm{A} \beta_{25-35^{-}}$and $\mathrm{CoCl}_{2^{-}}$ induced injuries was observed for trisphaeridine at $12.5 \mu \mathrm{M}$ relative to untreated cells [19]. Cell viability of $75.5 \%$ was observed after $\mathrm{H}_{2} \mathrm{O}_{2}$ treatment, $69.5 \%$ after $\mathrm{A} \beta_{25-35}$ treatment, and $92.6 \%$ after $\mathrm{CoCl}_{2}$ treatment relative to the untreated cells, which exhibited cell viabilities of $59.7 \%, 58.1 \%$, and $70.3 \%$, respectively [19].

Narcissus tazetta subsp. chinensis (M. Roem.) Masam. \& Yanagih. was examined for potential cytotoxic principles via $\mathrm{MeOH}$ extracts of its flowers [20]. Out of the 28 compounds isolated, including both alkaloid and nonalkaloid entities, 2 were identified as belonging to the trisphaeridine group: trisphaeridine (8) and 3-methoxy-3,4-dihydrotrisphaeridine (23) [20]. The MTT colorimetric assay was used to quantify the extent of proliferation of B16 4A5 melanoma cells in which melanogenesis had been initiated by theophylline stimulation [20]. Trisphaeridine (8) was shown to exhibit mild effects, with the best result (41.8\% inhibition) seen at the highest concentration of $100 \mu \mathrm{M}$, the other tested concentrations being 3, 10, and $30 \mu \mathrm{M}$ [20]. 3-Methoxy3,4-dihydrotrisphaeridine (23) fared better with $51.3 \%$ inhibition at a dosage of $30 \mu \mathrm{M}$, relative to arbutin $(61.5 \%$ at the equivalent concentration) [20]. Trisphaeridine (8) has also been identified in joint studies of the Brazilian plants Griffinia gardneriana (Herb.) Ravenna and Habranthus itaobinus Ravenna [21]. The cytotoxicity of trisphaeridine (8) was measured via MTT staining of HepG2 and MCF7 cancer cells and the normal murine L929 fibroblastic cell line [21]. In this manner, trisphaeridine (8) was shown to be inactive $\left(I C_{50} s>220 \mu \mathrm{M}\right)$ against the 3 cells relative to camptothecin, which restricted viabilities to just $15 \%$ when applied at $10 \mu \mathrm{M}$ [21]. However, the inactivity of trisphaeridine compared to camptothecin against the normal L929 cell line was noteworthy [21].

\section{The Bicolorine Group}

These types of compounds (such as the parent bicolorine 9) closely resemble trisphaeridine alkaloids but may be differentiated by the presence of an $\mathrm{N}$-methyl functionality [9]. Like trisphaeridine, they also display flattened architectures, thus considerably restricting the size of their molecules [9]. 5,6-Dihydrobicolorine (24) was the first of such compounds to be examined for antiproliferative effects [22]. It was isolated together with several other alkaloids from the Spanish plant Narcissus pseudonarcissus subsp. bicolor (L.) Baker. and subjected to a screen involving 2 human cancers (Molt4 T-lymphoma and HepG2) as well as a normal murine fibroblastic (LMTK) cell line [22]. 5,6-Dihydrobicolorine (24) proved to be highly selective based on its activity against the Molt4 $\left(\mathrm{ED}_{50} 0.8 \mu \mathrm{g} / \mathrm{mL}\right)$ and HepG2 $\left(\mathrm{ED}_{50}>50 \mu \mathrm{g} / \mathrm{mL}\right)$ cells (Table 2S, Supporting Information) [22]. This was, however, mitigated by its marked effect on the normal LMTK cell line $\left(E_{50} 0.7 \mu \mathrm{g} / \mathrm{mL}\right)$ as well as the potent activity of the positive con- 
trol (vincristine sulfate) against both cancers $\left(\mathrm{ED}_{50} \mathrm{~S} 0.04\right.$ and $0.01 \mu \mathrm{g} / \mathrm{mL}$, respectively) [22]. The investigation of Morikawa et al. (2016), alluded to above, also accounted for the presence of 5,6-dihydrobicolorine (24) in Narcissus tazetta subsp. chinensis [20]. This alkaloid's biological profile was then fashioned from its ability to inhibit theophylline-induced melanogenesis effects in B16 4A5 melanoma cells [20]. The best result observed for 5,6-dihydrobicolorine (24) was $61.7 \%$ inhibition of melanoma cell growth at a tested dosage of $30 \mu \mathrm{M}$, which closely matched that of the arbutin standard used $(61.5 \%$ inhibition at an equimolar concentration) [20].

In addition to the cytotoxic constituents described above in L. radiata [18], this plant also yielded 2-hydroxy-5,6-dihydrobicolorine (25) [23]. Eight separate tumor cell lines were used to examine this alkaloid's cytotoxic effects, including BEN-MEN-1 benign meningioma, CCF-STTG1 astrocytoma, CHG-5 oligodendroglioma, SHG-44 astrocytoma, U251 glioblastoma, HL-60, SMMC7721 hepatocellular carcinoma, and SW480 colon carcinoma cells [23]. Except for HL-60 cells against which low activity was observed ( $\left.\mathrm{IC}_{50} 81.3 \mu \mathrm{M}\right)$, 2-hydroxy-5,6-dihydrobicolorine (25) was inactive $\left(\mathrm{IC}_{50} \mathrm{~s}>100 \mu \mathrm{M}\right)$ against the remaining tumor cells [23]. These measurements were poor compared to the doxorubicin standard, which exhibited an impressive mean $\mathrm{IC}_{50}$ value of $25.4 \mathrm{nM}$ against all cells screened [23]. Further investigation of the Asian genus Lycoris led to the indigenous Chinese plant Lycoris aurea (L'Hér.) Herb. which yielded 8 compounds, 6 of which were identified as typical Amaryllidaceae alkaloid structures [24]. One of these was the novel compound 1,2-dihydroxy-5,6-dihydrobicolorine (26), a close relative of 2-hydroxy-5,6-dihydrobicolorine (25) that was identified prior in L. radiata [23]. No less than 7 human tumor cell lines were engaged for the cytotoxicity evaluation that accompanied the phytochemical study [24]. These included 4 squamous cells (SCL-1, UMSCC- 1 , SCC-PKU, TCA-83), 2 epithelial cells (Hep-2, CAL-27), and a single pharyngeal carcinoma cell line (Detroit-562). 1,2-Dihydroxy-5,6-dihydrobicolorine (26) was shown to be a poor cytotoxic agent against a majority of the cells $\left(\mathrm{IC}_{50} \mathrm{~s}>100 \mu \mathrm{M}\right)$, with low activity detected only in SCC-PKU squamous carcinoma cells ( $\left.\mathrm{IC}_{50} 87.6 \mu \mathrm{M}\right)$ [24]. These measurements were standardized against doxorubicin, which exhibited an impressive mean $\mathrm{IC}_{50}$ value of $0.023 \mu \mathrm{M}$ against the 7 cancer cells [24]. Among the 22 alkaloids isolated and identified from L. longituba was the bicolorine-related structure 5,6-dihydrobicolorine (24), subsequently examined for neuroprotective effects modeled on the SH-SY5Y neuroblastoma cell line [19]. This was estimated via the ability of 5,6-dihydrobicolorine (24) to buffer the cells from injuries induced by $\mathrm{H}_{2} \mathrm{O}_{2^{-}}, \mathrm{A} \beta_{25-35^{-}}$, or $\mathrm{CoCl}_{2}$ [19]. Accordingly, 5,6-dihydrobicolorine (24) was able to achieve this at the lowest tested concentration $(6.25 \mu \mathrm{M})$ as shown by cell viabilities of $65.7 \%, 70.9 \%$, and $70.9 \%$, respectively [19]. In the same instance, untreated cells reflected cell viabilities of $59.7 \%, 59.3 \%$, and $70.3 \%$, respectively [19].

Bicolorine (9) was identified in P. maritimum among 6 other alkaloids found in its $\mathrm{MeOH}$ bulb extract [16]. The accompanying PC-3 cell line examination showed dose-responsive effects at test concentrations of $5,10,20$, and $50 \mu \mathrm{M}$, with cell viability of $73 \%$ observed at $5 \mu \mathrm{M}$, which was markedly reduced to $29 \%$ by a 10 fold increase in concentration [16]. Compared to the standard
Z-4-ethylmercaptophenylmethylene hydantoin ( $\left.\mathrm{IC}_{50} 37.4 \mu \mathrm{M}\right)$, bicolorine (9) with its $\mathrm{IC}_{50}$ of $15 \mu \mathrm{M}$ was shown to be a better antiproliferative agent [16]. 5,6-Dihydrobicolorine (24) was among the 15 alkaloids described above from $Z$. candida and screened against HL-60, K562, A549, HepG2, and HT-29 cells [17]. Similar to the results seen for trisphaeridine (8) in the same study, 5,6-dihydrobicolorine (24) was poorly active against all 5 cell lines $\left(\mathrm{IC}_{50} \mathrm{~s}>40 \mu \mathrm{M}\right)$ compared to the anticancer drug taxol (mean IC $\mathrm{C}_{50}$ $0.08 \mu \mathrm{M})$ (Table 2S, see Supporting Information) [17].

\section{The Cherylline Group}

Cherylline-type alkaloids constitute a very small group within the Amaryllidaceae, which until recently was thought to be comprised of the 2 key representatives, cherylline (10) and latifine (27) [9]. Their structures harbor the basic isoquinoline motif onto which have been added, as with most Amaryllidaceae alkaloids, oxygen-related functionalities at the C- 6 and C-7 carbons of ring-A [9]. However, the delineating structural feature of these compounds is $\alpha$-arylation, which relates to the para-substituted aryl group that is stereoselectively bonded to the benzylic C-4 position of ring-B [9]. To date, only a single study has been carried out to ascertain the antiproliferative potential of cherylline and its congeners [25]. Crinum jagus (J.Thomps.) Dandy yielded 9 alkaloid structures, including cherylline (10), gigantelline (28), and gigantellinine (29), which were then examined for cytotoxic effects against MCF7 adenocarcinoma cells [25]. The tetrazolium stain XTT showed that cherylline (10), gigantelline (28), and gigantellinine (29) exhibited poor activities (cell viabilities $\geq 80 \%$ ) at most of the tested dosages $(0.4-100 \mu \mathrm{M})$ [25]. The best activities were seen at the highest concentration as reflected by cell viabilities of $15 \%, 70 \%$, and $80 \%$, respectively [25]. The activity for cherylline (10) at $400 \mu \mathrm{M}$ closely matched that of lycorine (4) (10\% cell viability), which was used as the positive control [25].

\section{The Galanthamine Group}

Through the prescription drug galanthamine (1), the parent compound of this alkaloid group, the Amaryllidaceae has been firmly installed as a biologically and chemically privileged plant family [26]. Structurally, they are tetracyclic compounds consisting of an aryl ring, a carbocyclic ring, and 2 heterocyclic rings [9]. Ring$A$ is a 1,2,3,4-tetrasubstituted aryl system, ring-B is a 1,2,3-trisubstituted heptenyl system, ring- $C$ is a dioxygenated $\alpha, \beta$-unsaturated hexyl system, and ring-D is a furanyl system with attachments to each of the other rings [9]. The distinguishing feature of galanthamine alkaloids is a spiro-junction at the confluence of rings $B$ and $C$ [9]. While most studies of these compounds understandably have focused on their motorneuron-related functions [26], significant effort as described here has also gone into probing their cytotoxic properties.

A noteworthy early study to record the antiproliferative effects of the Amaryllidaceae also had in its number 4 representatives from the galanthamine group of alkaloids [27]. Intriguingly, this time frame was well before the group became visible in the motorneuron arena [26]. As such, galanthamine (1), norgalanthamine (30), 3-epigalanthamine (31), and lycoramine (32) ( $\triangleright$ Fig. 1) were isolated from Narcissus tazetta L. and examined for cytotoxic effects against HeLa cells [27]. However, none of 
the compounds were able to significantly inhibit HeLa cell growth $(\mathrm{MICs}>400 \mu \mathrm{M})$ relative to the anticancer drug 6-mercaptopurine that was applied at $1 \mu \mathrm{M}$ [27]. This study, which incorporated no less than 18 different Amaryllidaceae alkaloid structures, is also significant in that it was the first to demonstrate the structure-dependent activities for these alkaloids [27]. Accordingly, while the galanthamine group (and other alkaloids) were inactive or poorly active on the HeLa cells, narciclasine (2), lycorine (4), and haemanthamine (5), which have since been established as the cytotoxic markers of the family, were notably active with MICs of $0.1,6.0$, and $4 \mu \mathrm{M}$, respectively [27]. A few years later, galanthamine (1) and lycoramine (32) from $N$. tazetta were examined for their effects on Rauscher leukemia [28]. In the study, NIH/3T3 murine fibroblastic cells were infected with the wild-type Rauscher leukemia virus, and the MTDs were determined based on the morphology and density of cells and the $\mathrm{pH}$ changes measured for the culture media [28]. These were determined for galanthamine (1) and lycoramine (32) to be $>200$ and $20 \mu \mathrm{g} / \mathrm{mL}$, respectively (Table 3S, Supporting Information) [28]. The potencies of narciclasine (2) and lycorine (4) over the galanthamine compounds were demonstrated by their respective MTD values of 0.005 and $0.2 \mu \mathrm{g} / \mathrm{mL}$ [28]. An additional investigation of $N$. tazetta led to the identification of galanthamine (1), lycoramine (32), and narwedine (33) from its bulb extract [29]. Five human cancers, including MCF7, HeLa, K562, CEM lymphoblastic leukemia, and G-361 malignant melanoma cells, were selected to probe the cytotoxic effects of the isolated alkaloids [29]. The only activity detected for the $3 \mathrm{~N}$. tazetta isolates was that of narwedine (33) against CEM cells ( $\left.\mathrm{IC}_{50} 31.6 \mu \mathrm{M}\right)$ relative to staurosporine $\left(\mathrm{IC}_{50}\right.$ $0.023 \mu \mathrm{M})$, with $I C_{50}$ values shown to be $>50 \mu \mathrm{M}$ in all other instances [29]. Despite this poor showing against the cancer cells, galanthamine (1), lycoramine (32), and narwedine (33), when examined for effects against normal cells, were all inactive against B] fibroblasts $\left(\mathrm{IC}_{50} \mathrm{~s}>50 \mu \mathrm{M}\right)$ [29].

The study by Weniger et al. (1995) described earlier involved a screen of 25 different alkaloid structures from various species of the Amaryllidaceae against Molt4, HepG2, and LMTK cells [22]. Included in the library were the galanthamine representatives galanthamine (1), norgalanthamine (30), and $\mathrm{N}$-formylgalanthamine (34), which were obtained from bulbs of Narcissus confusus Pugsley and Narcissus nivalis Graells [22]. The MTT colorimetric assay indicated good activities for norgalanthamine (30) and $\mathrm{N}$-formylgalanthamine (34) (ED 50 s 0.6 and $1.6 \mu \mathrm{g} / \mathrm{mL}$, respectively) compared to galanthamine (1) $\left(\mathrm{ED}_{50}>50 \mu \mathrm{g} / \mathrm{mL}\right)$ against the Molt4 cell line [22]. Only $N$-formylgalanthamine (34) $\left(\mathrm{ED}_{50}\right.$ $9.0 \mu \mathrm{g} / \mathrm{mL}$ ) was active against HepG2 cells, the remaining 2 compounds reflecting $\mathrm{ED}_{50}$ values that were over $50 \mu \mathrm{g} / \mathrm{mL}$ [22]. By contrast, the reference compound vincristine sulfate exhibited $\mathrm{ED}_{50} \mathrm{~s}$ of 0.04 and $0.01 \mu \mathrm{g} / \mathrm{mL}$ against both of these cell lines, respectively [22]. Despite these cancer cell line activities, all 3 alkaloids were also very active on the nontumoral LMTK cells $\left(\mathrm{ED}_{50} \mathrm{~S}\right.$ $0.5,0.5$, and $0.6 \mu \mathrm{g} / \mathrm{mL}$, respectively) [22]. The poor activity of galanthamine (1) against the HepG2 cell line was later ratified in a separate study [30] where cell viabilities $>85 \%$ were detected with all tested concentrations and time intervals [30]. As many as 23 different alkaloid substances were found in Narcissus cv. Professor Einstein, among which were the galanthamine representa- tives lycoraminone (35) and norlycoramine (36) [31]. Nine cell lines were chosen in the antitumor screen using the WST-1 assay to ascertain the alkaloids' antiproliferative effects [31]. Despite the cell line diversity, lycoraminone (35) and norlycoramine (36) were shown to be inactive, with cell viabilities that were $>90 \%$ in all cases relative to doxorubicin (mean value $26.3 \%$ ) [31]. The study's positive aspect was that neither compound was active on the normal fetal lung fibroblast cell line MRC-5, where cell viabilities measured were $96 \%$ and $108 \%$, respectively [31].

Studies on Phaedranassa dubia (Kunth) J.F. Macbr. led to the identification of 8 alkaloids, among which were the galanthamine compounds galanthamine (1), 3-epinorgalanthamine (37), and sanguinine (38) [32]. The attendant cytotoxicity evaluation involved L6 rat myoblasts, where all 3 compounds exhibited negligible effects $\left(\mathrm{IC}_{50} \mathrm{~s}>300 \mu \mathrm{M}\right)$ [32]. Two galanthamine-type compounds viz. galanthamine (1) and chlidanthine (39) were identified in the Andean representative Chlidanthus fragrans Herb. [33]. HT-29 and Caco-2 colon adenocarcinoma cells from the ATCC were used in the complementary cytotoxicity evaluation of both alkaloids [33]. In the event, galanthamine (1) and chlidanthine (39) exhibited weak activities against HT-29 (IC 50 $_{5} 49.3$ and $52.7 \mu \mathrm{M}$, respectively) and Caco-2 ( $\mathrm{IC}_{50} \mathrm{~s} 61.4$ and $72.9 \mu \mathrm{M}$, respectively) relative to lycorine (4) (mean $\left.\mathrm{IC}_{50} 1.1 \mu \mathrm{M}\right)$ [33]. However, the study demonstrated that both compounds were relatively nontoxic to normal FHs-74 intestinal epithelial cells $\left(\mathrm{IC}_{50} \mathrm{~s}\right.$ 67.6 and $78.1 \mu \mathrm{M}$, respectively) [33]. The weak activity for galanthamine (1) against the normal cell line is significant given its usage in Alzheimer's disease chemotherapeutics [26]. Chlidanthine (39) from Chlidanthus fragrans then became part of a library of 22 alkaloids that was subjected to a general cytotoxicity screen against 16 different cancer cell lines [34]. Also included in the library were lycoramine (32) (from Zephyranthes robusta (Herb. ex Sweet) Baker), narwedine (33) (from Narcissus poeticus L.), and the quaternary salt galanthamine hydrobromide (40) that was obtained from a commercial source [34]. It was shown that with a few exceptions, the cell viabilities produced by lycoramine (32), narwedine (33), chlidanthine (39), and galanthamine hydrobromide (40) were mostly >90\% [34]. These estimations were made against doxorubicin as a control for which a mean cell viability of $28 \%$ was determined [34]. This lack of cell line anticancer effects was matched by the performance of the 4 compounds on noncancerous NHDF cells, wherein cell viabilities were unaffected $(93 \%$, $103 \%, 96 \%$, and $98 \%$, respectively) [34]

Phytochemical studies of the Brazilian plant Hippeastrum solandriflorum (Lindl.) Herb. yielded 8 alkaloids, amongst which were identified galanthamine (1), sanguinine (38), and galanthamine$\mathrm{N}$-oxide (41) [35]. The antiproliferative effects of all isolated compounds were then measured against 4 human cancers including HCT-116 colon carcinoma, HL-60, OVCAR8 ovarian carcinoma, and SF-295 glioblastoma [35]. Negligible effects ( $\left.\mathrm{IC}_{50} \mathrm{~S}>50 \mu \mathrm{M}\right)$ were observed for all 3 alkaloids against OVCAR8 and SF-295 cells, as well as galanthamine (1) and galanthamine- $N$-oxide (41) against HCT-116 and HL-60 cells [35]. Sanguinine (38) was the only compound of the set that showed activities against the latter 2 of these cell lines, although at 29.0 and $32.1 \mu \mathrm{M}$, respectively, they were mild compared to the standard doxorubicin (mean $\mathrm{IC}_{50} 0.17 \mu \mathrm{M}$ ) [35]. Sanguinine (38) was one of several alkaloid 
principles identified in a bulb extract of the Brazilian native Griffinia gardneriana as alluded to earlier in the text [21]. Cytotoxicities against both HepG2 and MCF7 cancer as well as normal L929 cells were determined via the MTT spectrophotometric method [21]. Intriguingly, sanguinine (38) proved to be twice as active on the normal cell line $\left(\mathrm{IC}_{50} 91.1 \mu \mathrm{M}\right)$ compared to the tumor cells, where $\mathrm{IC}_{50} \mathrm{~s}$ in each case were $>180 \mu \mathrm{M}$ [21]. Sanguinine has also been described in Crinum jagus, one of 9 alkaloids to have been so done [25]. These were then exposed to the MCF7 cell line, wherein viabilities were ascertained by XTT staining [25]. Sanguinine (38) was shown to be inactive as cell viabilities were seen to be $\sim 100 \%$ at most of the tested concentrations [25].

The Japanese plant Lycoris albiflora Koidz. yielded 15 alkaloids, including galanthamine (1), lycoramine (32), and lycoramine- $N$ oxide (42), as members of the galanthamine group of alkaloids [36]. The biological component of the study utilized HL-60 cells with which to probe the antiproliferative action of the isolated alkaloids [36]. None of the 3 compounds proved to be active $\left(\mathrm{IC}_{50} \mathrm{~S}>55 \mu \mathrm{M}\right)$ (Table 3S, Supporting Information), with the reference standard etoposide shown to be far superior ( $\mathrm{IC}_{50} 0.42 \mu \mathrm{M}$ ) [36]. In addition to the phytochemical and biological study described above [24], L. aurea has been pursued further for its cytotoxic alkaloid principles [37]. It yielded 13 alkaloid structures including 4 galanthamine analogs that were identified as galanthamine (1), norgalanthamine (30), N-chloromethylgalanthamine (43), and N-chloromethyllycoramine (44) [37]. In the study's cytotoxicity component, the MTT spectrophotometric test was used to establish the neuroprotectiveness of the isolated compounds from $\mathrm{CoCl}_{2}$ - and $\mathrm{H}_{2} \mathrm{O}_{2}$-induced injuries in $\mathrm{SH}-\mathrm{SY} 5 \mathrm{Y}$ cells [37]. Significant protection from $\mathrm{CoCl}_{2}$-induced injury was observed at most tested levels with only galanthamine (1), norgalanthamine (30), and $\mathrm{N}$-chloromethylgalanthamine (43) offering no such effect at the lowest concentration $(6.25 \mu \mathrm{M})$, although the differences in these instances were minimal compared to untreated cells [37]. By contrast, all 4 alkaloids were able to significantly protect $\mathrm{SH}-\mathrm{SY} 5 \mathrm{Y}$ cells from injuries that were $\mathrm{H}_{2} \mathrm{O}_{2}$-based, with cell viability of $73.3 \%$ shown for norgalanthamine (30) at the lowest tested concentration relative to untreated cells (67.3\% viable) [37]. Complementing the description of 2-methoxy-1,2,3,4-tetrahydrotrisphaeridine (22) in the study of $L$. radiata was the isolation of the galanthamine alkaloid 3-epidihydrosanguinine (45) from its EtOH bulb extract [18]. As previously noted, A549 and LoVo cells were used in the adjoining component of the study to measure the cytotoxic effects of the isolated alkaloids [18]. However, 3-epidihydrosanguinine (45) proved to be weak at such activity, with $\mathrm{IC}_{50} \mathrm{~S}$ in each case $>20 \mu \mathrm{M}$ relative to doxorubicin (mean $\mathrm{IC}_{50} 0.53 \mu \mathrm{M}$ ) [18]. Twenty-two alkaloids referred to earlier were identified in bulb extracts of the Chinese medicinal plant L. longituba, among which were 7 members of the galanthamine group of alkaloids [19]. These were identified by spectroscopic means as galanthamine (1), norgalanthamine (30), sanguinine (38), $\mathrm{N}$ chloromethylgalanthamine (43), $\mathrm{N}$-chloromethyllycoramine (44), $11 \beta$-hydroxygalanthamine (46), and 9-O-demethyllycoramine (47) [19]. The cytotoxicity aspect of the study involved a probe to determine if any of these alkaloids could protect SH-SY5Y neuroblastoma cells from injuries induced by $\mathrm{H}_{2} \mathrm{O}_{2}, \mathrm{~A} \beta_{25-35}$, or $\mathrm{CoCl}_{2}$ [19]. It was seen that all of these alkaloids at 5 dosage levels (6.25,
$12.5,25,50$, and $100 \mu \mathrm{M}$ ) offered significant neuroprotection from such injuries [19]. Notable responses were observed after cells were treated with galanthamine (1) and N-chloromethyllycoramine (44) at the lowest tested concentration following exposure to $\mathrm{A} \beta_{25-35}$ and $\mathrm{H}_{2} \mathrm{O}_{2}$, respectively [19]. SH-SY5Y cell viabilities in these instances were $80.7 \%$ and $82.3 \%$ relative to untreated cells that reflected viabilities of $77.1 \%$ and $72.3 \%$, respectively [19].

Commercial grade galanthamine was the substrate employed in additional studies of the SH-SY5Y neuroblastoma cell line [38]. In this case, the alkaloid's protectiveness was estimated via its ability to influence $A \beta_{1-42}$-mediated toxicity in SH-SY5Y cells [38]. Giesma staining was used to ascertain the clonogenic survival of cells [38], showing a $70 \%$ survival rate at the low dosage $(0.1 \mu \mathrm{M})$ and as high as $95 \%$ survival in cells receiving $10 \mu \mathrm{M}$ galanthamine [38]. Interestingly, galanthamine alone (i.e., without applying $A \beta_{1-42}$ ) at its maximum concentration did not affect the survival of the SH-SY5Y cells [38]. Further studies of neuroprotection of SH-SY5Y cells involved a probe of the parent compound galanthamine (1) from Phaedranassa lehmannii Regel [39]. Galanthamine (at $3 \mu \mathrm{g} / \mathrm{mL}$ ) had little effect on the viability of $\mathrm{SH}$ SY5Y cells (>90\%) as determined by spectrophotometric means after MTT staining [39]. Also, galanthamine (at $0.3 \mu \mathrm{g} / \mathrm{mL}$ ) was able to protect cells from the adverse effects of rotenone/oligomycin $A(3: 1)$, in which cell viability of $80 \%$ was determined [39]. Similarly, cell viability of $75 \%$ was observed when cells treated prior with galanthamine $(0.3 \mu \mathrm{g} / \mathrm{mL})$ were exposed to okadaic acid (20 nM) [39].

\section{The Montanine Group}

Montanine alkaloids are characterized by their B-ring moieties, which are 7-membered nitrogen-containing heterocycles [9]. A further diagnostic feature of their structures is the presence of a methano-bridge that straddles ring- $B$ between the nitrogen and C-11 positions [9]. As expected, this feature introduces considerable strain to the molecule, dividing ring- $B$ into 2 parts [9]. The first part comprising the nitrogen atom, C-6, C-6a, C-10a, and C11 is nearly as flat as the aryl A-ring, while the second part made up of C-4a and C-11a (and the nitrogen atom and C-11) is forced out of the plane to become perpendicular to the first part (and to ring-A) [9]. Consequently, ring- $C$ adopts a near-perfect boat conformation with C-2 and C-4a as the bow and stern parts and connectivities to ring-B occurring via C-4a and C-11a [9]. Ring-C usually also incorporates double bond and oxygen-related functionalities in its structure [9]. The first report on the cytotoxic effects of montanine alkaloids was produced after a dual phytochemicalbiological study of the Ukrainian plant Narcissus angustifolius Curt. [40]. The first part of the study involved the isolation of 7 alkaloids, including the 2 montanine analogs nangustine (48) and pancracine (49) [40]. Normal L6 mouse myoblasts were utilized in the second aspect of the study to measure the cytotoxicities of the isolated compounds [40]. Encouragingly, neither compound could elicit any response in the myoblast cells wherein $\mathrm{ED}_{50} \mathrm{~s}$ were $>90 \mu \mathrm{g} / \mathrm{mL}$, respectively [40]. It has been outlined above that phytochemical investigation of the cultivar Narcissus cv. Professor Einstein yielded 23 alkaloids [31]. Among these alkaloids identified by their spectroscopic and spectrometric data, the dihydroxy 
montanine analog pancracine (49) was one of the plant's major constituents [31]. The cytotoxicity probe involved 9 cell lines, one of which was the normal human fibroblast cell line MRC-5 [31]. Pancracine was shown to be active against all 8 cancer cells, with $\mathrm{IC}_{50} \mathrm{~S}$ of between 2-3 $\mu \mathrm{M}$ observed against Molt4, A549, HT29, MCF7, and SAOS-2 cells (Table 4S, Supporting Information) [31], while the effects on the remaining cells (Jurkat, A2780, HeLa) were more subdued $\left(\mathrm{IC}_{50} \mathrm{~s} \sim 5 \mu \mathrm{M}\right)$ [31]. However, the overall effect of pancracine (49) (mean IC $503.5 \mu \mathrm{M}$ ) was over 10-fold less than that observed for the standard doxorubicin (mean $\mathrm{IC}_{50}$ $0.3 \mu \mathrm{M})$ [31]. Nonetheless, pancracine $\left(\mathrm{IC}_{50} 5.2 \mu \mathrm{M}\right)$ proved to be far less toxic to the normal MRC-5 cell line compared to doxorubicin $\left(\mathrm{IC}_{50} 0.7 \mu \mathrm{M}\right)$ [31].

Pancracine (49) was among several alkaloids identified in Pancratium canariense Ker Gawl. [41]. The library's montanine component was expanded to include a further 2 chloride analogs (50 and 51) acquired by semisynthetic manipulations [41]. Cytotoxic effects against 4 human tumor cell lines, including A2780 (ovary), SW1573 (lung), T-47D (breast), and WiDr (colon), were determined via the sulforhodamine B assay $48 \mathrm{~h}$ after incubation with the respective alkaloids [41]. In the event, pancracine (49) and the chloride analog 50 were significantly active, with mean $\mathrm{GI}_{50}$ values of 7.1 and $5.9 \mu \mathrm{M}$, respectively [41]. The best activity seen for pancracine (49) was against SW1573 cells (GI $50.3 \mu \mathrm{M})$, while that for compound 50 was in the $A 2780$ cell line $\left(G_{50} 3.4 \mu \mathrm{M}\right)$ [41]. Compound 51 reflected $\mathrm{GI}_{50} \mathrm{~s}>100 \mu \mathrm{M}$ against 3 of the cells tested, with weak activity seen against the one remaining (A2780, $\mathrm{GI}_{50} 75.2 \mu \mathrm{M}$ ) [41]. The cancer cell line activities for pancracine (49) are noteworthy since it was previously shown to be inactive on nontumoral L6 mouse myoblasts [40]. In continued attempts to probe the cancer cell line effects of semisynthetic analogs of montanine (13) ( $\vee$ Fig. 3) [41], a library of such compounds was assembled via a series of elegant chemical maneuvers [42]. These all emanated from the $\alpha$-crinane parent compound haemanthamine (5), which, under basic conditions, has been amenable toward transformation into the montanine skeleton [42]. Interestingly, the natural compound manthine (52), a C-2 methoxy analog of montanine, was also secured in good yield from haemanthamine (5) [42]. The 14 other analogs $(50,53-65)$ bore varying degrees of structural diversity that significantly amplified the variability of the montanine library that was subsequently examined for cytotoxic effects [42]. The panel of cell lines included those that were inherently either resistant (A549 lung carcinoma, SKMEL-28 melanoma, U373 glioblastoma) or sensitive (MCF7 breast adenocarcinoma, Hs683 oligodendroglioma, B16F10 murine melanoma) to proapoptotic stimuli [42]. Manthine (52) was identified as the pick of the compound library (mean $\mathrm{GI}_{50}$ $3.7 \mu \mathrm{M})$, with good activities seen for it across both the sensitive and resistant cell lines [42]. Notable responses were also observed with some of the semisynthetic analogs such as 53 (mean $\mathrm{Gl}_{50}$ $11.5 \mu \mathrm{M}), 55$ (mean $\left.\mathrm{GI}_{50} 13.0 \mu \mathrm{M}\right), 58$ (mean $\left.\mathrm{GI}_{50} 14.5 \mu \mathrm{M}\right)$, and 64 (mean $\left.\mathrm{Gl}_{50} 13.8 \mu \mathrm{M}\right)$ [42].

The study of the Brazilian plant Hippeastrum vittatum (L'Hér.) Herb. is significant because it was the first to unravel the potential of montanine alkaloids as cytotoxic agents [43]. The fresh bulb EtOH extract yielded 3 known alkaloids, one of which was the parent compound montanine (13) [43]. The cell lines used for the study included HT-29 (colon adenocarcinoma), H460 (non-small cell lung carcinoma), RXF393 (renal cell carcinoma), MCF7 (breast cancer), and OVCAR3 (epithelial ovarian cancer) [43]. Montanine (13) exhibited good activities against several Hippeastrum cultivars, including Hippeastrum cv. Ferrari, Hippeastrum cv. Double King, Hippeastrum cv. Pretty Nymph, and Hippeastrum cv. Spartacus [44]. In this instance, the cells screened were the same 9 used above by Breiterova and co-workers (2020) [31]. Here, montanine exhibited $\mathrm{IC}_{50} \mathrm{~s}<1.5 \mu \mathrm{M}$ in most of the cells, except for PANC-1 ( $\left.\mathrm{IC}_{50} 2.3 \mu \mathrm{M}\right), \mathrm{A} 2780\left(\mathrm{IC}_{50} 1.7 \mu \mathrm{M}\right)$, and HeLa (IC $\left.502.0 \mu \mathrm{M}\right)$ cells [44].

Lycoris longituba, a Chinese medicinal herb, yielded several alkaloids from its bulb extract, as indicated earlier [19]. Lycolongirine C (66) was identified from its spectroscopic data as belonging to the montanine group of alkaloids [19]. In addition to possessing a quaternized nitrogen atom, lycolongirine $C$ is unique in that the methano-bridge within its structure adopts a $\beta$-configuration [19]. Its cytotoxic potential was ascertained via its ability to alleviate injuries to $\mathrm{SH}-\mathrm{SY} 5 \mathrm{Y}$ neuroblastoma cells induced by $\mathrm{H}_{2} \mathrm{O}_{2}, A \beta_{25-35}$, and $\mathrm{CoCl}_{2}$ [19]. Significant protection was observed for lycolongirine $C(66)$ at the lowest tested concentration $(6.25 \mu \mathrm{M})$ against $\mathrm{H}_{2} \mathrm{O}_{2}$-induced injury, with cell viability in this instance shown to be a robust $90.4 \%$ relative to untreated cells (72.6\%) [19]. The effect was attenuated following both $A \beta_{25-35}$ (68.1\% versus $58.1 \%$ ) and $\mathrm{CoCl}_{2}$ (69.7\% versus $\left.70.8 \%\right)$ treatments [19]. Montabuphine (67) was a further member of this group found among several alkaloids in the Chinese plant Lycoris sprengeri Comes ex Baker [45]. Although a significant quantity (40 mg) of this compound was isolated from the dried bulb material, surprisingly, it was not included, as others were, in the screen for neuroprotective effects in $\mathrm{SH}-\mathrm{SY} 5 \mathrm{Y}$ cells after exposure to $\mathrm{H}_{2} \mathrm{O}_{2}$, $\mathrm{A} \beta_{25-35}$, and $\mathrm{CoCl}_{2}[45]$.

Several representatives of the Southern African genus Haemanthus are known to be producers of alkaloids belonging to the montanine group of compounds [4]. Therefore, the finding that 2 of the 4 alkaloids isolated from Haemanthus humilis Jacq. were montanine-type alkaloids was not surprising [46]. After chromatographic and spectroscopic analyses, they were identified as montanine (13) and coccinine (68) [46]. The cell lines used for the cytotoxicity tests were sourced from the ATCC and included breast MCF7, Hs578T, MDA-MB-231, colon HCT-15, lung A549, and melanoma SKMEL-28 [46]. As such, montanine (13) was identified as the pick of the 2 compounds, with $I_{50} s<5 \mu \mathrm{M}$ in 4 of the 6 cell lines examined [46]. Its best activity was against $A 549$ cells $\left({ }^{\prime} C_{50}\right.$ $1.9 \mu \mathrm{M})$, while the melanoma cell line SKMEL-28 proved to be least susceptible to montanine exposure $\left(\mathrm{IC}_{50} 23.2 \mu \mathrm{M}\right)$ [46]. Coccinine (68) exhibited $\mathrm{IC}_{50} \mathrm{~s}$ that were between 5-10 $\mu \mathrm{M}$ against $\mathrm{A} 549$, MCF7, and Hs578T, while values of 15-20 $\mu \mathrm{M}$ were seen for HCT15 and MDA-MB-231 cells [46]. Interestingly, coccinine was also poorly active on the SKMEL-28 cell line $\left(\mathrm{IC}_{50}>50 \mu \mathrm{M}\right)$ [46].

\section{The Lycosinine Group}

This group of alkaloids, such as lycosinine B (14), are by definition 7-arylindoline entities [9]. In terms of Amaryllidaceae alkaloid chemosystematics, they may be considered as truncated analogs of the more recognizable lycorine (4) and homolycorine (12) alkaloids of the family [9]. It can be seen that the conversion of 


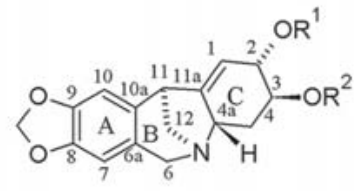

13. $\mathrm{R}^{1}=\mathrm{CH}_{3}, \mathrm{R}^{2}=\mathrm{H}$ (Montanine)

49. $R^{1}=R^{2}=H$ (Pancracine)

52. $\mathrm{R}^{1}=\mathrm{R}^{2}=\mathrm{CH}_{3}$ (Manthine)

53. $\mathrm{R}^{1}=\mathrm{H}, \mathrm{R}^{2}=\mathrm{CH}_{3}$

54. $\mathrm{R}^{1}=\mathrm{CH}_{2} \mathrm{CH}_{3}, \mathrm{R}^{2}=\mathrm{CH}_{3}$

55. $\mathrm{R}^{1}=$ allyl, $\mathrm{R}^{2}=\mathrm{CH}_{3}$

56. $\mathrm{R}^{1}=$ propargyl, $\mathrm{R}^{2}=\mathrm{CH}_{3}$

57. $\mathrm{R}^{1}=\mathrm{N}$-benzyl, $\mathrm{R}^{2}=\mathrm{CH}_{3}$

58. $\mathrm{R}^{1}=3$-indolo, $\mathrm{R}^{2}=\mathrm{CH}_{3}$

59. $\mathrm{R}^{1}=2$-pyrrolo, $\mathrm{R}^{2}=\mathrm{CH}_{3}$<smiles>COC1C=C2C3Cc4cc5c(cc4C[C@]2(CC1O)[NH+](CCl)C3)OCO5</smiles>

66. Lycolongirine $\mathrm{C}$
Montanine group

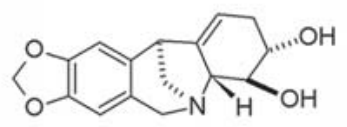

48. Nangustine

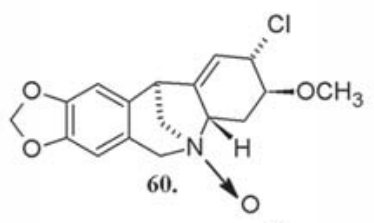<smiles>[R20][R]#[R][H]</smiles>

63. $\mathrm{R}^{1}=\mathrm{R}^{2}=\mathrm{I}$<smiles>CO[C@H]1C[C@@H]2C(=C[C@H]1O)C1CN2Cc2cc3c(cc21)OCO3</smiles>

67. Montabuphine

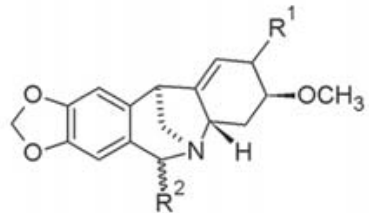

50. $\mathrm{R}^{\prime}=\alpha-\mathrm{Cl}, \mathrm{R}^{2}=\mathrm{H}$

51. $\mathrm{R}^{1}=\alpha-\mathrm{Cl}, \mathrm{R}^{2}=\mathrm{OCH}_{3}$

64. $R^{1}=\beta-B r, R^{2}=H$

65. $\mathrm{R}^{1}=\alpha-\mathrm{OH}, \mathrm{R}^{2}=\mathrm{OMes}$<smiles>C#CCN1Cc2cc3c(cc2[C@@H]2C[C@@H]1[C@@H](Br)C[C@H]2Br)OCO3</smiles><smiles></smiles>

68. Coccinine

Lycosinine group

Augustamine group<smiles>COc1cc(C=O)c(-c2cccc3c2N(C)CC3)cc1OC</smiles>

14. Lycosinine B<smiles>COCc1cc(OC)c(OC)cc1C1C2C(=CC[C@@H]1O)C(O)C(OC)N2C</smiles>

69. Lycolongirine $B$<smiles>CN1CCC2=CC[C@@H](O)C(c3cc4c(cc3CO)OCO4)[C@H]21</smiles>

82. Tetrahydromasonine

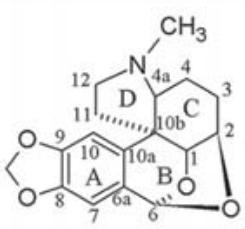

15. Augustamine

\section{Cripowellin group}

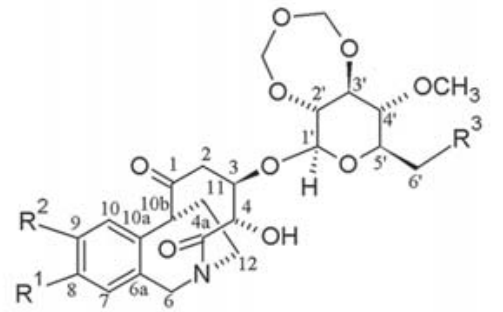

16. $\mathrm{R}^{1}+\mathrm{R}^{2}=\mathrm{OCH}_{2} \mathrm{O}, \mathrm{R}^{3}=\mathrm{OH}$ (Cripowellin A)

71. $\mathrm{R}^{1}+\mathrm{R}^{2}=\mathrm{OCH}_{2} \mathrm{O}, \mathrm{R}^{3}=\mathrm{H}$ (Cripowellin $\mathrm{C}$ )

73. $\mathrm{R}^{1}=\mathrm{R}^{2}=\mathrm{OCH}_{3}, \mathrm{R}^{3}=\mathrm{H}$

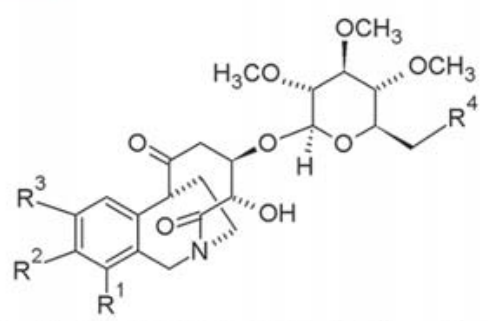

70. $\mathrm{R}^{1}=\mathrm{H}, \mathrm{R}^{2}+\mathrm{R}^{3}=\mathrm{OCH}_{2} \mathrm{O}, \mathrm{R}^{4}=\mathrm{OH}($ Cripowellin $\mathrm{B})$ 72. $\mathrm{R}^{1}=\mathrm{R}^{4}=\mathrm{H}, \mathrm{R}^{2}+\mathrm{R}^{3}=\mathrm{OCH}_{2} \mathrm{O}$ (Cripowellin $\mathrm{D}$ )

74. $\mathrm{R}^{1}=\mathrm{R}^{4}=\mathrm{H}, \mathrm{R}^{2}=\mathrm{R}^{3}=\mathrm{OCH}_{3}$

75. $\mathrm{R}^{1}=\mathrm{OCH}_{3}, \mathrm{R}^{2}+\mathrm{R}^{3}=\mathrm{OCH}_{2} \mathrm{O}, \mathrm{R}^{4}=\mathrm{OH}$

76. $\mathrm{R}^{1}=\mathrm{H}, \mathrm{R}^{2}=\mathrm{R}^{4}=\mathrm{OH}, \mathrm{R}^{3}=\mathrm{OCH}_{3}$

- Fig. 3 Cytotoxic agents in the montanine, lycosinine, augustamine and cripowellin alkaloid groups of the Amaryllidaceae. 
lycosinine B (14) into a homolycorine compound is a straightforward operation involving B-ring lactonization to connect C-6 to C-1 via its carboxylate [9]. Conversion to a lycorane compound would require a $180^{\circ}$ rotation about the C-10a/C-10b bond, $\mathrm{N}$-demethylation, and ring-B closure via imine formation or lactamization [9]. Lycosinine B (14) was amongst 24 alkaloids mentioned above identified in the Chinese plant L. sprengeri [45]. However, the paucity of material obtained precluded any further investigation into its neuroprotective effects in SH-SY5Y cells [45].

By contrast, 22 alkaloids were described from the Chinese medicinal plant $L$. longituba, among which was the highly functionalized lycosinine-type alkaloid lycolongirine B (69) [19]. In this instance, all of the isolated compounds were examined for protective effects on SH-SY5Y neuroblastoma cells that were primed with $\mathrm{H}_{2} \mathrm{O}_{2}(300 \mu \mathrm{M}), \mathrm{A} \beta_{25-35}(1 \mu \mathrm{M})$, or $\mathrm{CoCl}_{2}(265 \mu \mathrm{M})$ [19]. Lycolongirine $B(69)$ was seen to be most effective in all cases at its lowest tested concentration $(6.25 \mu \mathrm{M})$ out of 2-fold serial dilutions starting from $100 \mu \mathrm{M}$ [19]. The cell viabilities observed for treated and untreated cells were as follows: after $\mathrm{H}_{2} \mathrm{O}_{2}$ exposure (60.9\%, 51.5\%); after $A \beta_{25-35}$ exposure $(78.3 \%, 74.4 \%)$; after $\mathrm{CoCl}_{2}$ exposure $(61.7 \%, 54.4 \%)$ [19]. Apart from these limited studies, a further 3 papers were identified that probed the mechanistic aspects related to the cytotoxicity of lycosinine alkaloids, as will be discussed later in the text $[12,13,47]$.

\section{The Augustamine Group}

These alkaloids have a narrow distribution in the Amaryllidaceae, where they have to date been located only in the genus Crinum L., notably in Crinum x amabile Donn ex Ker Gawl., Crinum kirkii Baker, and Crinum latifolium L. [48-51]. Structurally, they are similar to homolycorine alkaloids in that their $A, B$, and $C$ rings constitute a phenanthridine system, wherein ring- $B$ (as in the latter) is also a pyran moiety [9]. However, augustamine alkaloids may be distinguished by the positioning of ring- $D$, which is attached to ring- $C$ via $\mathrm{C}-4 \mathrm{a}$ and $\mathrm{C}-10 \mathrm{~b}$, an attachment that occurs via $\mathrm{C}-4$ and $\mathrm{C}-4 \mathrm{a}$ in homolycorine-type compounds [9]. A further marker for these alkaloids is the presence of an ether bridge between C-2 and C-6, which goes into making up the highly strained 1,3-dioxolane ring system [9]. Following the description of augustamine (15) in Crinum $x$ augustum Roxb. (synonym Crinum $x$ amabile Donn ex Ker Gawl.) [48], a preliminary screen showed it to be inactive against Molt4 T-lymphoma cells [52]. More recently, interest in the cytotoxic properties of these compounds has been rekindled [50,51]. The Asian medicinal plant $C$. latifolium yielded 11 alkaloid entities from its $\mathrm{MeOH}$ leaf extract, one of which was identified as augustamine (15) [50]. However, it was subsequently shown via the SRB method to be inactive $\left(\mathrm{IC}_{50} \mathrm{~S}>100 \mu \mathrm{M}\right)$ against 5 cancer cells (KB, HepG2, MCF7, SKMEL-2, and LNCaP) that formed the cytotoxicity component of the study [50]. The following study involved a phytochemical and biological examination of Crinum $x$ amabile, an Asian representative that was nevertheless sourced from a naturalized population in Espirito Santo (Brazil) [51]. In the process, 25 alkaloid constituents, including augustamine (15), were isolated from $\mathrm{MeOH}$ bulb extracts and identified using spectrometric and spectroscopic techniques [51]. Examined against normal L6 mouse myoblasts, augustamine (15), encouragingly, exhibited poor activity $\left(\mathrm{IC}_{50} 81.6 \mu \mathrm{g} / \mathrm{mL}\right.$ ) [51]. By comparison, the standard drug podophyllotoxin was in parallel screening far more potent (IC $500.004 \mu \mathrm{g} / \mathrm{mL})[51]$.

\section{The Cripowellin Group}

Cripowellins may be considered as B,C, D-seco-analogs of crinane alkaloids [9]. All compounds described to date have the ethanobridge positioned in an $\alpha$-fashion, similar to those seen for the $\alpha$ crinane series of alkaloids (such as haemanthamine 5) [9]. Interestingly, they have thus far only been seen in the genus Crinum, particularly Crinum x powelli Baker, Crinum latifolium L. and Crinum erubescens L.f. ex Aiton [53-55]. Although cripowellins A and B $(16,70)$ were first described over 2 decades ago [53], their re-isolation and biological examination have only ensued in recent years $[54,55]$. Considerable excitement has been generated from such observations that have pinned these alkaloids as among the most active Amaryllidaceae alkaloids, with nanomolar level activity against some of the cell lines examined [54,55]. Dried aerial parts of $C$. erubescens afforded 5 alkaloids after $\mathrm{MeOH}$ extraction, chromatographic separation, and spectroscopic analysis [54]. Four of these were identified as cripowellins $A, B, C$, and $D(16,70,71$, 72 ), which were then tested for antiproliferative effects on the human ovarian cancer cell line A2780 [54]. In all instances, potent activities were observed as reflected by $\mathrm{IC}_{50}$ values of 0.011 , $0.016,0.025$, and $0.028 \mu \mathrm{M}$, respectively [54]. Cripowellin A (16), together with 4 other novel cripowellins $(73,74,75,76)$, were recently isolated from the Chinese medicinal plant Crinum latifolium L. collected at Yongning in the Guanxi Province [55]. While previous studies of $C$. latifolium yielded alkaloids that were readily identifiable with the Amaryllidaceae [56], the investigation by Chen and co-workers (2018) noteworthily led to the isolation of the unusual cripowellin compounds presumably due to the exceedingly large amount of fresh bulb material $(400 \mathrm{~kg})$ used in the extraction process [55]. The screen for cytotoxic effects involved 6 cell lines, all of which were lung cancer variants, including A549, H446, H460, H292, 95-D, and SPCA-1 [55]. Compounds 75 and 76 were the most active in the series (mean $I_{50} \mathrm{~s} 0.009 \mu \mathrm{M}$, respectively) [55]. The best activities observed for compounds 75 and 76 were against $\mathrm{H} 292$ and $\mathrm{H} 446$ cells $\left(\mathrm{IC}_{50} \mathrm{~s} 0.007 \mu \mathrm{M}\right.$, respectively) [55]. All measurements were carried out against the reference standard doxorubicin, which exhibited a mean $\mathrm{IC}_{50}$ value of $0.023 \mu \mathrm{M}$ across the 6 cells [55].

\section{Structure-activity Relationships}

The impressive array of structural diversity that Amaryllidaceae alkaloids display has served them well in attempts to understand the features by which their cytotoxic effects may be modulated [8]. The essential details of the anticancer pharmacophore are reasonably well-understood based on both semisynthetic modifications and target-orientated total syntheses [8]. However, such attempts have primarily been pursued with phenanthridone, lycorane, and crinane alkaloids in mind [8]. Nonetheless, the significant number of targets from the minor alkaloid groups already screened for antiproliferative effects, as shown herein, have provided valuable information about the features attending their respective pharmacophores. Furthermore, such information has facilitated a better understanding of the cytotoxic effects associated with the more recognized alkaloid groups of the family. 
Starting with the Amaryllidaceae alkaloid precursor group (the belladine group), it was seen that none of its representatives (4-Omethylnorbelladine $18,4-\mathrm{O}, \mathrm{N}$-dimethylnorbelladine 19 , or $4-\mathrm{O}, \mathrm{N}$ dimethylnorbelladine- $N$-oxide 20) were active against $K B$ or HCT116 cells $[10,11]$. Although limited in scope, these results are highly informative as they affirm at the outset that the cytotoxic effects of Amaryllidaceae alkaloids are built upwards from their belladine precursors in increasing layers of structural, chemical, and electronic complexity. Furthermore, they highlight that rigid structure formulation, as found in the phenanthridone, lycorane, and crinane alkaloid groups, is required for cytotoxicity. These are contrasted against the belladine compounds wherein the 2 aryl rings, since they are benzylic, would experience significant degrees of free rotation. Since compounds 18, 19, and 20 are functionalized belladine analogs, it remains to be ascertained what effects the parent compounds such as belladine (6) and norbelladine (17) might have on cancer cells. Based on the evidence, though, it is fair to assume that they would be poor cytotoxic agents. Despite this lack of cancer cell line activity, there are other notable aspects to the anticancer properties of belladine-type compounds, particularly concerning how they manifest these activities, as is covered in the succeeding section of the text.

The ismine group was also shown to spawn compounds, such as ismine (7) and norismine (21) ( $\bullet$ Fig. 2), that were devoid of cytotoxic activities in separate studies of HeLa, MCF7, L5178 PAR, L5178 MDR, and PC-3 cells $[15,16]$. Furthermore, $N$-demethylation in the series (as in norismine 21) appears to have no bearing on activity [16]. Ismine compounds are characterized by the installation of a carbon-carbon bond between rings $B$ and $C$, a step forward from their belladine precursor [3]. However, this additional structural element is insufficient to potentiate any of their cytotoxic effects $[15,16]$. This notwithstanding, there are mechanistic aspects to the cytotoxicity of ismine alkaloids worth considering, as is done in the section following this one.

The formation of ring- $B$, to afford the isoquinoline motif and attendant adjustments (such as C-ring oxidations), are the operations that appear to fortify the cytotoxic responses of Amaryllidaceae alkaloids [8]. The simplest of such a transformation can be envisaged for norismine (21) (via its aldehyde), which could be readily converted to the iminium analog trisphaeridine (8) via hydrolytic intramolecular cyclization. Similarly, ismine (7) (the $\mathrm{N}$ methylated biphenyl) would afford bicolorine (9) as the cyclized $\mathrm{N}$-methyl iminium ion. The activities observed for trisphaeridine (8) in most cell lines examined were moderate to mild $[15,17$, 20]. However, trisphaeridine (8) did notably buffer SH-SY5Y neuroblastoma cells from injuries induced by $\mathrm{H}_{2} \mathrm{O}_{2}, A \beta_{25-35}$, and $\mathrm{CoCl}_{2}$ [19]. Furthermore, there were slight improvements in activities for the partially-saturated (23) or fully-saturated (22) C-ring trisphaeridine analogs in A549, LoVo, and B16 4A5 melanoma cells $[18,20]$. This indicates that the loss of C-ring aromaticity (and concomitant planarity), together with the introduction of oxygen-related functionalities (as in 22 and 23), are the features that serve to potentiate the effects of the anticancer pharmacophore. That this is indeed the case may be seen directly through the polyhydroxylated C-ring variants such as narciclasine (2) and pancratistatin (3), the standout examples of the family in the cancer arena [8]. Some insightful aspects of the cytotoxicity of tri- sphaeridine (8) from a mechanistic perspective have been addressed in the literature, as discussed later in this review.

Overall, the bicolorine (9) alkaloids proved to be more active than their close relatives in the trisphaeridine (8) group of alkaloids. Bicolorine (9) ( $\left.\mathrm{IC}_{50} 15 \mu \mathrm{M}\right)$ was more effective than Z-4-ethylmercaptophenylmethylene hydantoin (IC $5037.4 \mu \mathrm{M})$ in inhibiting the growth of PC-3 cells [16]. Although 5,6-dihydrobicolorine (24) was inactive $\left(\mathrm{IC}_{50} \mathrm{~S}>40 \mu \mathrm{M}\right)$ against $\mathrm{HL}-60, \mathrm{~K} 562, \mathrm{~A} 549$, HepG2, and HT-29 cells [17], it (61.7\%) was able to match arbutin (61.5\%) when it came to inhibiting B16 4A5 melanoma cell growth [20]. Its most impressive response was against the Molt4 cell line $\left(\mathrm{ED}_{50} 0.8 \mu \mathrm{g} / \mathrm{mL}\right)$ [22]. Further modifications to the bicolorine skeleton were seen to be at the expense of activities as seen via 2-hydroxy-5,6-dihydrobicolorine (25) and 1,2-dihydroxy-5,6dihydrobicolorine (26) in separate exposures to as many as 15 different cancer cell types $[23,24]$. Trisphaeridine (8) and bicolorine (9) differ only by the presence of the $\mathrm{N}$-methyl group in the latter, indicating that such an enhancement is beneficial to the anticancer pharmacophore. Although there were no cell lines available for direct comparison purposes, the evidence suggests that 5,6-dihydrobicolorine (24) is more active than bicolorine (9), indicating that the flow of charge back to the nitrogen atom as well as a hybridization shift from sp2 to sp3 at C-6 is advantageous. The case of zephycandidine $A(77)$ is a curious one. While it possesses 2 diagnostic structural elements of bicolorine (9) viz. a trisubstituted B-ring nitrogen atom as well as a C-6 sp2 center, these have somewhat capriciously been incorporated into a 1,3-imidazole ring system [57]. The "externalization" of the imine functionality in zephycandidine A (77), which distinguishes it from bicolorine (9), appears to consolidate the potent cytotoxic effects of this imidazolium compound [57]. It exhibited a mean $\mathrm{IC}_{50}$ of $5.04 \mu \mathrm{M}$ in a 5-cell screen involving HL-60, A549, MCF7, SW480, and SMMC7721 cells that was superior to that of cis-platin (mean $\mathrm{IC}_{50}$ $10.35 \mu \mathrm{M})$ [57]. Zephycandidine A (77) $\left(\mathrm{IC}_{50} 20.08 \mu \mathrm{M}\right)$, as desired, even proved to be less effective than cis-platin (mean $\mathrm{IC}_{50}$ $13.30 \mu \mathrm{M})$ against normal Beas-2B bronchial epithelial cells [57]. These impressive activities, in hindsight, are perhaps not as surprising given that phenanthridones such as arolycoricidine (78) and narciprimine (79), with an oxo group at C-6, are known for their potent cytotoxic effects [5,8].

The key anticancer alkaloid group of the Amaryllidaceae, as mentioned prior, is the phenanthridone group, whose members are characterized by A-ring methylenedioxyphenyl, B-ring lactam, and $\mathrm{C}$-ring polyhydroxy functionalities $[5,8]$. The next group in line in terms of potency is the lycorane group, wherein the key feature is the ethano-tether linking the nitrogen atom to C-4 and thus forming ring-D [8]. In the crinane alkaloid group, the ethanobridge is rerouted so that in forging ring-D, it spans the nitrogen and $\mathrm{C}-10 \mathrm{~b}$ positions via the $\alpha$ - or $\beta$-face of the molecule [8]. Divergence from the features typifying these 3 alkaloid groups, in general, may be viewed as detrimental to the anticancer pharmacophore. As seen for the belladine, ismine, trisphaeridine, and bicolorine groups above, this is also true for the remaining alkaloid groups of the Amaryllidaceae. To this extent, the 3 cherylline-related compounds (cherylline 10, gigantelline 28, gigantellinine 29) were all inactive against breast adenocarcinoma MCF7 cells [25]. Compared to phenanthridone, lycorane, and crinane alka- 
loids, cherylline-type alkaloids lack A,C-ring connectivity, which in the latter occurs indirectly via the C-4 benzylic carbon [9]. Although good activities were seen for a few representatives of the tazettine (11) and homolycorine (12) alkaloid groups [58, 59], these were outmatched as expected by the phenanthridone, lycorane, and crinane groups [8]. The lycosinine group is intriguing because its members maintain features that exemplify both lycorane and homolycorine alkaloids [9]. As such, the activities for lycosinine-related compounds would be expected to be somewhere in between these latter 2 groups of alkaloids. Although a wider range of cells still needs to be examined for this premise to be validated, a single study of lycolongirine B (69) showed that it offered significant protection to SH-SY5Y neuroblastoma cells from injuries induced by $\mathrm{H}_{2} \mathrm{O}_{2}, A \beta_{25-35}$, or $\mathrm{CoCl}_{2}$ [19]. Augustamine-type alkaloids also bear some resemblance to the homolycorine alkaloids and, as such, would be expected to be poorly cytotoxic [9]. In this regard, augustamine (15) was inactive against as many as 6 different cell lines, including Molt4, KB, HepG2, MCF7, SKMEL-2, and LNCaP $[50,52]$. These results also substantiate the notion that a shift in direction from lycorine (4) to homolycorine (12) is to the detriment of the cytotoxic pharmacophore $[50,52]$.

Given the significance of galanthamine-type alkaloids in the motorneuron disease arena, it may be construed that their cytotoxic effects should be negligible at best or mild at worst. However, this is not the case, as seen in the section above for some representatives of this group. Encouragingly, galanthamine (1) itself proved to be inactive against most cancer cell lines screened. Also appealing was the fact that it displayed negligible effects on some normal cell lines, such as BJ fibroblasts and L6 myoblasts $[29,32]$. There were some concerns, however, over the fact that galanthamine (1), norgalanthamine (30), and $N$-formylgalanthamine (34) ( $\triangleright$ Fig. 1) displayed potent activities in the evaluation of nontumoral LMTK fibroblast cells $\left(E_{50} s 0.5,0.5\right.$, and $0.6 \mu \mathrm{g} /$ $\mathrm{mL}$, respectively) [22]. In the instances where galanthamine (1) displayed significant effects, they were related to protection from injuries to SH-SY5Y neuroblastoma cells, a coveted response in the motorneuron disease area [19,37-39]. O-Demethylation of galanthamine (1) to afford sanguinine (38) (also a natural product) is highly prized in the motorneuron terrain since the latter is over 10 times more potent than the former in the inhibition of AChE [26]. Although there was some improvement in HCT-116 and HL-60 cells, sanguinine in parallel screening with galanthamine was mostly inactive $[25,32,35]$. This suggests that the A-ring methoxy to hydroxy transformation, involving a shift from a hydrogen bond acceptor function to a hydrogen bond donor-acceptor function, may be slightly beneficial in the cytotoxicity realm. The effect of ring-B modification has been probed via 4 adjustments: (i) $\mathrm{N}$-demethylation, (ii) quaternization of the nitrogen atom, (iii) $\mathrm{N}$-oxide bond formation, and (iv) hydroxy substitution. Although a limited number of studies have probed the effects of $\mathrm{N}$-demethylation, the results suggest that such a maneuver is beneficial towards the cytotoxicity of these alkaloids. Norgalanthamine (30) $\left(E_{50} 0.6 \mu \mathrm{g} / \mathrm{mL}\right)$ was among the most active of the 25 Amaryllidaceae alkaloids exposed to the Molt4 lymphoma cell line, the same instance in which galanthamine (1) displayed an $\mathrm{ED}_{50}$ of $>50 \mu \mathrm{g} / \mathrm{mL}$ [22]. Norgalanthamine (30) was also capable of buffering SH-SY5Y neuroblastoma cells from the deleterious effects of $\mathrm{H}_{2} \mathrm{O}_{2}, \mathrm{~A}_{25-35}$, and $\mathrm{CoCl}_{2}[19,37]$. By removing the $\mathrm{N}$ methyl group, the charge would increase around the nitrogen atom, explaining the increase in cytotoxicity for norgalanthamine (30). Oxidation of the $\mathrm{N}$-methyl group to an $\mathrm{N}$-formyl (as in $\mathrm{N}$-formylgalanthamine 34) would also tend to pull charge away from the nitrogen atom via delocalization (instead of induction in galanthamine). Hence, $N$-formylgalanthamine (34) $\left(E_{50} 1.6 \mu \mathrm{g} / \mathrm{mL}\right)$ was less active than norgalanthamine $(30)\left(E_{50} 0.6 \mu \mathrm{g} / \mathrm{mL}\right)$ but far more potent than galanthamine $(1)\left(E D_{50}>50 \mu \mathrm{g} / \mathrm{mL}\right)$ against Molt4 cells [22]. Quaternization of the nitrogen atom has been achieved via protonation (as in galanthamine hydrobromide 40) and alkylation (as in N-chloromethylgalanthamine 43) [19,34, 37]. However, only $\mathrm{N}$-chloromethylgalanthamine (43) was able to ameliorate the deleterious effects of $\mathrm{H}_{2} \mathrm{O}_{2}, \mathrm{~A} \beta_{25-35}$, and $\mathrm{CoCl}_{2}$ in SH-SY5Y cells $[19,37]$. Since quaternization would not only deplete the charge around the nitrogen atom but also completely reverse it so that it becomes a cationic species, such a conversion is cytotoxically disadvantageous. In the formation of an $\mathrm{N}$-oxide (as in galanthamine- $N$-oxide 41) [35], the bond formed is a dative covalent bond with charge, as expected, shifting from the nitrogen to the oxygen atom. This, as outlined above and seen via the lack of activity of galanthamine- $N$-oxide (41) against 4 human cancers (HCT-116, HL-60, OVCAR8, SF-295), appears to be detrimental to the cytotoxic pharmacophore [35]. One example involves introducing a substituent at a carbon atom in ring- $B$, which is $11 \beta$-hydroxygalanthamine (46) [19]. Although this compound is yet to be tested against a wider variety of cell lines, it did offer $\mathrm{SH}$ SY5Y neuroblastoma cells protection from injuries induced by $\mathrm{H}_{2} \mathrm{O}_{2}, \mathrm{~A} \beta_{25-35}$, and $\mathrm{CoCl}_{2}$ [19].

The modifications probed for ring- $C$ include (i) oxidation of the C-3 hydroxyl, (ii) substitution at C-3, and (iii) reduction of the double bond. Compared to the former, it was seen that although narwedine (33) was mildly active against CEM cells ( IC $\left._{50} 31.6 \mu \mathrm{M}\right)$ [29], it was inactive against as many as 16 different cancer lines as seen via cell viabilities that were mostly $>90 \%$ [34]. In narwedine (33), the oxo group is predisposed to hydrogen bond acceptor functions compared to galanthamine (1), where the hydroxy group would manifest both donor and acceptor functions. Furthermore, narwedine (33) is characterized by $\alpha, \beta$-unsaturation and the consequent flattening of ring- $C$, which, together with the acceptor functions of the oxo group, could explain its better activity over galanthamine [29]. The evidence available suggests that C-3 substitution as with chlidanthine (39) offers no benefit as this compound was inactive (or poorly active) against as many as 18 cancer cells $[33,34]$. Both of these studies involved a screen in parallel with galanthamine (1), which, as expected, was also inactive $[33,34]$. The C-3 methoxy group in chlidanthine (39) negates the hydrogen bond donor feature linked to the C-3 hydroxyl group. Reduction of the double bond to afford lycoramine (32) offered no benefits against any of the cell lines examined. This has been verified separately for norlycoramine (36), which was inactive in a screen of 9 cell lines [31]. Its parent compound, norgalanthamine (30) (with the double bond in the C-4/C-4-a position), by contrast, was identified among the most potent Amaryllidaceae alkaloids against the Molt4 lymphoma cell $\left(E_{50} 0.6 \mu \mathrm{g} / \mathrm{mL}\right)$ [22]. Given that the furanyl D-ring except for its C-1 methine car- 
bon, is fully substituted, little can be achieved in modifying its structure; hence all of the compounds examined reflected an intact D-ring.

Similar to the galanthamine compounds described immediately above, significant effort has gone into attempts to modify the montanine (13) ( $\vee$ Fig. 3) nucleus. Given that ring-A is a tetrasubstituted aryl ring system, little can be achieved by further adjusting its structure [9]. However, there were 2 attempts made to functionalize the vacant $\mathrm{C}-7$ and $\mathrm{C}-10$ positions, by which the iodo compounds 62 and 63 were accessed [42]. Despite this, none of these compounds were active on a series of cancer cells that included both apoptosis-resistant and apoptosis-sensitive cells [42]. The adjustments explored for ring-B include C-6 substitution, $\mathrm{N}$-oxide formation, and quaternization of the nitrogen atom. However, oxygen-related substituents at C-6 (51 and 65) had no effect when exposed to 10 different cancer cell lines [41,42]. The $\mathrm{N}$-oxide product $(60)\left(\right.$ mean $\left.\mathrm{Gl}_{50}>100 \mu \mathrm{M}\right)$ was far less active in a 6 -cell screen than its unoxidized precursor (50), which exhibited a mean $\mathrm{Gl}_{50}$ value of $18.8 \mu \mathrm{M}$ [42]. The assumption here, like that observed for the galanthamine oxides above, is that $\mathrm{N}$-oxidation would have the effect of pulling charge away from the nitrogen atom leading to a decrease in cytotoxicity [42]. Similarly, quaternization of the nitrogen atom as in compound 61 (mean $\mathrm{Gl}_{50}>100 \mu \mathrm{M}$ ) had a gross negative effect on its cytotoxicity against 6 different cancer cell lines relative to its parent compound (50) (mean $\mathrm{Gl}_{50} 18.8 \mu \mathrm{M}$ ) [42].

Understandably, most SAR-based studies of montanine-type alkaloids have focused on the 2,3-dihydroxy system constituting the hexyl C-ring. Significantly, a few of these were themselves natural product entities as opposed to semisynthetic derivatives based on the montanine scaffold. The parent compound montanine (13) was identified among the most potent montanine-type alkaloids, with submicromolar level activities against a significant number of cell lines $[43,44,46]$. Interestingly, upon selective C-2 functionalization with various electrophiles, the resulting products (54-59) to a large extent were able to sustain their activities against 6 cancer cells that were either susceptible to or resistant to proapoptotic stimuli [42]. This was previously observed for the phenanthridone and lycorine groups, wherein monosubstitution of the 1,2-dihydroxy system was seen to fortify the anticancer pharmacophore [8]. The understanding here is that such substitutions would negate the hydrogen bond acceptor capacity of the methoxy group but increase bulk and lipophilicity around the C-2 region of montanine (13), which may be viewed as beneficial. Furthermore, maintaining the size and polarity of the $\mathrm{C}-2$ substituent was shown to potentiate the activities of the resultant products [42]. Compounds 50 and 64 were among the most potent compounds screened by Govindaraju et al. (2018) against A549, SKMEL-28, U373, MCF7 Hs683, and B16F10 cells [42]. The C-2 halide substituents in compounds 50 and 64 would participate in hydrogen bond acceptor reactions and exert an influence via their innate electronegativities. Interestingly, switching the methoxy and hydroxy functionalities was also seen to potentiate the activities of the product (53) in the same 6 cancer cells above [42]. In this instance, hydrogen bond donor-acceptor functions would shift to the C-2 position (compared to C-3 in montanine 13) [42]. Epimerization of the C-2 methoxy group was also a detrimental operation, as montanine (13) markedly outperformed coccinine (68) in a 6 cancer cell line screen [46]. This is contrasted against the halide compounds 50 and 64 , which have opposite configurations at $\mathrm{C}-3$, yet were both able to sustain their activities [42]. Shifting the substituents from $\mathrm{C}-2 / \mathrm{C}-3$ (as in montanine 13) to C$3 / \mathrm{C}-4$ (as in nangustine 48 ) would be expected to be detrimental [40]. Although there is a lack of data suggesting otherwise, nangustine (48) was inactive against L6 myoblastic cells [40]. Despite a lack of data to the contrary, it is expected that a radical transformation where the $\mathrm{N}$-to- $\mathrm{C}-11$ methano-bridge adopts a $\beta$-configuration and C-4a becomes $R$-configured (as in montabuphine 67) would lessen the potency of montanine-type alkaloids [45].

The most potent compounds of the minor alkaloid groups of the Amaryllidaceae are to be found within the cripowellin group, most of whose members exhibited nanomolar level cytotoxic activities $[54,55]$. Structurally, they are reminiscent of the crinane alkaloids such as haemanthamine (5), which are characterized by a $N$-to-C-10b $\alpha$-ethano bridge [9]. The distinguishing features of cripowellin compounds are the lack of the $\mathrm{C}-4 \mathrm{a} / \mathrm{C}-10 \mathrm{~b}$ bond, with $\mathrm{C}-4 \mathrm{a}$ in the process bearing an oxo group, and the presence of $\beta$ glycosylated moieties at C-3 [9]. Therefore, it can be construed that these compounds' potencies must be related primarily to their close structural similarity to the $\alpha$-crinane alkaloids [54,55]. Furthermore, seeing that they are more potent cytotoxic agents than their $\alpha$-crinane congeners, this enhancement must be due to the glycosylated functionalities. Since such functionalities are rare in the Amaryllidaceae, it would be interesting to establish if glycosylated analogs from the various alkaloid groups in the family potentiate the effects of their parent alkaloids.

\section{Mechanistic Insight}

Since recognizing the phenanthridone alkaloids of the Amaryllidaceae as promising anticancer drugs, much effort has been diverted to understanding how they manifest their action [8]. Given the hierarchy of the other minor alkaloid groups in the cancer area, significantly less information is available on how they might carry out their cytotoxic effects. Most of the evidence described here suggests a considerable overlap of such modes of action with those seen for the phenanthridone, lycorane, and crinane alkaloids [8]. One of the earliest studies to explore this direction is the one carried out by jimenez et al. (1976) involving a screen of several Amaryllidaceae alkaloids for their in vitro protein inhibitory effects in eukaryote cells [27]. Using endomyocarditis viral RNA as a messenger, it was seen that galanthamine (1), norgalanthamine (30), 3-epigalanthamine (31), or lycoramine (32) (at concentrations as high as $1 \mathrm{mM}$ ) were not capable of inhibiting protein synthesis in S-30 ascites [27]. Narciclasine (2), lycorine (4), and haemanthamine (5), by comparison, were potent inhibitors of this process and at far lower concentrations [27]. Furthermore, it was demonstrated via the fragment reaction that while narciclasine (2), lycorine (4), and haemanthamine (5) all dose-dependently inhibited peptide bond formation in S-30 ascites ribosomes, galanthamine (1), norgalanthamine (30), 3-epigalanthamine (31), and lycoramine (32) did not [27]. However, studies carried out some years later found that several Amaryllidaceae alkaloids could interact with macromolecules [60]. In the event, the minor alkaloid representatives galanthamine (1) and ismine (7) (at $0.5 \mathrm{mg} /$ 
$\mathrm{mL}$ ) exhibited significant binding affinities to calf thymus DNA (63.5\% and 31.5\%, respectively) [60]. These activities were all seen to be better than that for lycorine (4) (25.0\%) but markedly lower than that observed for haemanthamine (5), which is on record to have among the best binding potencies (99.6\%) to calf thymus DNA $[60,61]$. The anticancer drug reference standard vinblastine in the same instance reflected a binding affinity of $98.2 \%$ [60].

In the study of Molt4, HepG2, and LMTK cells above, it was seen that, with some exceptions, better overall activities were observed for the 25-alkaloid library against the nontumoral LMTK fibroblast cell line than the cancer cells [22]. The minor alkaloid representatives galanthamine (1), 5,6-dihydrobicolorine (24), norgalanthamine (30), and $\mathrm{N}$-formylgalanthamine (34) exhibited $\mathrm{ED}_{50}$ values that were between 0.5 and $0.7 \mu \mathrm{g} / \mathrm{mL}$ [22]. Since LMTK cells are known to be enriched with cytoskeletal protein entities, it was suggested that the cytotoxicity of Amaryllidaceae alkaloids might be due to their detrimental effects on the cytoskeleton [22]. That this could be the case has been ratified in recent times for some key cytotoxic principles of the Amaryllidaceae [62,63]. Narciclasine (2), for example, was shown to impair glioblastoma multiforme proliferation by diminishing mitotic rates without inducing apoptosis in Hs683 and U373 glioma cells, a diagnostic feature of which was actin stress fiber formation [63]. Also, narciclasine exhibited potent cytotoxic effects against a series of both apoptosis-sensitive and apoptosis-resistant cancer cells, a characteristic of which was its ability to impair the organization of the actin cytoskeleton [62]. The cripowellins, as discussed earlier, were characterized by their interesting structures and potent antiproliferative activities [54,55]. Interestingly, cripowellin B (70) (at $10 \mu \mathrm{M})$ had prior been shown to manifest its deleterious effects in A375 melanoma, SW620 colon, and HeLa cervical tumor cells by inhibiting tubulin polymerization [64]. Weniger et al. (1995) observed that most constituents in the diverse 25 -alkaloid library exhibited poor activities against the HepG2 hepatoma cell line [22]. It was suggested that this intrinsic resistance was a consequence of the catabolic activity of the heme-containing mono-oxygenase enzyme cytochrome P450 (CYP450), which under metabolic conditions is known to be functional in HepG2 cells [22]. Interestingly, narciclasine (2) (Ki $0.63 \mu \mathrm{M})$ was among the most active of the Amaryllidaceae alkaloids tested for CYP3A4 inhibition [65]. Given this observation, it remains to be established whether narciclasine does attenuate HepG2 cell proliferation. CYP3A4 is responsible for metabolizing roughly $60 \%$ of all drugs consumed by humans, thus affording a reliable buffer against drug overload [66].

Another way that the body can deal with xenobiotic substances (including drugs) is by expulsive means utilizing ATP-binding proteins, such as the efflux pump protein P-glycoprotein (P-gp) [67]. $\mathrm{P}$-gp is also expressed in several human cancers where it contributes to chemotherapeutic resistance [67]. It was observed above that ismine (7) and trisphaeridine (8) exhibited poor activities against both the PAR (L5178 PAR) and MDR (L5178 MDR) forms of mouse lymphoma [15]. A further aspect of this study was a probe via Rh-123 accumulation to gauge if these alkaloids could reverse multidrug resistance in L5178 MDR cells via efflux pump inhibition [15]. This was an extension to observations made prior for other alkaloids such as lycorine (4) and haemanthamine (5), which were seen to harbor moderate efflux pump inhibitory abilities [61]. However, at $40 \mu \mathrm{g} / \mathrm{mL}$ neither ismine (7) nor trisphaeridine (8) displayed significant efflux pump inhibitory effects as indicated by their fluorescence activity ratios $(R)$ of $<2$, respectively, compared to the standard verapamil $(R \sim 3)$ [15]. The fluorescence activity ratio can be defined as the ratio of the fluorescence determined for treated versus untreated cells [15]. Thus, these alkaloids were deemed poor substrates for P-gp in the L5178 MDR cell line [15]. However, at $400 \mu \mathrm{g} / \mathrm{mL}$, a dramatic spike in the fluorescence ratio was determined for trisphaeridine $(R \sim 50)$, indicating that its effects on P-gp were possible at higher concentrations [15]. Apart from this, montanine (13) and coccinine (68) both demonstrated low binding affinity to P-gp as seen via low inhibition of calcein-AM efflux in the MDCK-MDR1 cell line [68]. While important in the regulation of xenobiotic substances on the one hand [67], these results indicate on the other hand that P-gp efflux will not limit the blood-brain barrier passage of these or related alkaloids of the family should they realize clinical fruition $[15,68]$.

The minor alkaloid group representative trisphaeridine (8) has also been found in Crinum yemense Deflers (synonym Crinum album (Forssk.) Herb.), one of 9 alkaloids to have been done so from $\mathrm{MeOH}$ bulb extracts of the plant [69]. In conjunction with this, the isolated compounds were also examined for inhibitory effects on nitric oxide (NO) production and induction of inducible nitric oxide synthase (iNOS) [69]. However, trisphaeridine (8) exhibited no observable effect on NO production in LPS-stimulated mouse peritoneal macrophages relative to guanidinoethyl disulfide (GED) [69]. It also did not affect the expression and inhibition of iNOS relative to the standard nonselective inhibitor $\mathrm{N}$-monomethyl-L-arginine (L-NMMA) [69]. By contrast, lycorine (4) (IC 50 $2.5 \mu \mathrm{M})$ was shown to be more potent than GED $\left(\mathrm{IC}_{50} 7.4 \mu \mathrm{M}\right)$ at inhibiting NO production in the macrophage cells [69]. iNOS is associated with processes where there is a propensity for the overproduction of $\mathrm{NO}$ and can also be expressed in response to proinflammatory elements, such as interleukin-1 $\beta$ (IL-1 $\beta$ ), tumor necrosis factor- $\alpha$ (TNF- $\alpha$ ), and lipopolysaccharide (LPS) in macrophages, endothelial cells, and smooth muscle [70]. The role of iNOS in cancer is not clear, but it is understood that high levels of it can be either cytostatic or cytotoxic to tumor cells. In contrast, low levels can have the opposite effect and promote tumor growth [70].

Several lines of evidence indicated galanthamine to be a poor cytotoxic agent toward HepG2 hepatoma cells [21, 22, 30]. For example, all 4 tested galanthamine concentrations $(0.1,1,10$, $100 \mu \mathrm{M}$ ) produced cell viabilities greater than $85 \%$ [30]. Furthermore, in the same study, galanthamine (1) was shown not to affect DNA condensation, ROS production, generation of MDA, glutathione depletion, redox status, and MMP of the HepG2 cells [30]. DNA condensation, ROS production, and fluctuations in MMP are significant as markers in cells undergoing apoptosis, as observed for some representatives of the phenanthridone, lycorane, and crinane alkaloids of the Amaryllidaceae [8]. Selective apoptosis-inducing effects, for example, have been identified as the key strategy by which narciclasine (2), lycorine (4), and haemanthamine (5) manifest their cytotoxicity in cancer cells [8]. The fact that galanthamine (1) could not mediate in such a course 
of action in HepG2 cells underlines its status as a reputable Alzheimer's drug [30].

Another area probed for the minor alkaloids in the mechanistic arena is their interaction with the DNA-associated topoisomerases [8]. These enzymes are known for their integral functions in DNA topology regulation, particularly its overwinding or underwinding [71]. The clinical application of such action is apparent in targeted antibacterial therapy through the fluoroquinolone class of antibiotics, which are among the most effective medicines administered as bacterial type II topoisomerase inhibitors [71]. Interestingly, since elevated topoisomerase levels are also detectable in rapidly dividing cells, such as cancer cells, it has been suggested that targeted blocking of such activity could be of relevance in cancer chemotherapy [71]. Topoisomerase inhibition has been observed for some lycorane and phenanthridone class alkaloids of the Amaryllidaceae [8]. The pheanthridones arolycoricidine (78) and narciprimine (79) at relatively low dosages (0.1$0.25 \mu \mathrm{g} / \mathrm{mL}$ ) were able to markedly inhibit topoisomerase types I and II [72]. Apart from this, the B-seco alkaloid ismine (7) from Crinum powellii Baker has been probed for topoisomerase inhibitory activity in the yeast Saccharomyces cerevisiae [73]. In the event, its response was measured against 2 strains of $S$. cerevisiae, the wildtype strain RAD+ and the mutant strain RAD52Y [73]. Ismine (7) was inactive against both strains with $\mathrm{IC}_{12}$ values in each case shown to be $>2000 \mu \mathrm{g} / \mathrm{mL}$ [73]. Lycorine (4), which was also found in C. powellii, was shown to be over 7 times more active against the mutant RAD52Y strain $\left(\mathrm{IC}_{12} 218.7 \mu \mathrm{g} / \mathrm{mL}\right)$ than the wild-type RAD+ strain $\left(\mathrm{IC}_{12} 1542.7 \mu \mathrm{g} / \mathrm{mL}\right)$ [73]. Since the mutant strain is characterized by DNA repair-deficiency, lycorine activity (4) is a good indicator of its topoisomerase activity [73]. This can be extrapolated to reflect cancer cells, where there are significant topoisomerase activity levels and extraordinarily high levels of DNA activity [71].

It was earlier seen that out of the 2 minor alkaloid constituents of $P$. maritimum, bicolorine (9) was a better antiproliferative agent than norismine (21) against the effects of $\mathrm{PC}-3$ prostate cancer cells [16]. The adjoining component of this study was the test via the wound healing assay (WHA) to ascertain what effects these compounds had on PC-3 cell migration [16]. Here too bicolorine (9) exhibited better activity than norismine (21), allowing only $38.1 \%$ migration of PC-3 cells compared to $100 \%$ for the latter [16]. At the equimolar concentration $(50 \mu \mathrm{M})$ of the test substrates, the standard antimigratory compound Z-4-ethylmercaptophenylmethylene hydantoin permitted $23.8 \%$ migration [16]. Apart from this, it has prior been seen that some alkaloids of the Amaryllidaceae possessed encouraging anti-invasive activities [74]. Although the inhibition of metastasis and tumor invasion are attractive possibilities in cancer chemotherapy, a drug for either of these processes is still to see commercial fruition [75]. While the most promising anticancer drug targets of the Amaryllidaceae (such as narciclasine 2 ) are viewed primarily as selective apoptosis inducers, the fact that they can mediate in tumor invasion is also encouraging [74]. For example, 2,3,4,7-0-tetraacetylnarciclasine $(80)($ at $0.1 \mu \mathrm{M})$ allowed only $2 \%$ invasion of collagen type I fibers by HeLa tumor cells [74].

Several studies outlined above have been used to examine the neuroprotective effects of Amaryllidaceae alkaloids [19,37-39,
45]. All of these had the SH-SY5Y neuroblastoma cell line in common as the target to probe the cytotoxicity-related effects of Amaryllidaceae alkaloids $[19,37-39,45]$. SH-SY5Y cells were initially cloned from the bone marrow of a neuroblastoma sufferer. Since they are phenotypically adrenergic but also express some dopaminergic markers, they are particularly useful in the study of neurodegenerative diseases [76]. The suggestion made in consideration of the effects of galanthamine (1), norgalanthamine (30), $\mathrm{N}$ chloromethylgalanthamine (43), and $\mathrm{N}$-chloromethyllycoramine (44) against $\mathrm{CoCl}_{2}$ - and $\mathrm{H}_{2} \mathrm{O}_{2}$-induced injuries in $\mathrm{SH}-\mathrm{SY} 5 \mathrm{Y}$ cells was that they could be of neuroprotective benefit in instances involving hypoxic injury or oxidative damage, such as in neurodegeneration but also brain cancers [37]. The same suggestion has been made concerning the neuroprotective effects of several alkaloids from $L$. longituba against not only $\mathrm{CoCl}_{2}$ - and $\mathrm{H}_{2} \mathrm{O}_{2}$-induced injuries but also those caused by the amyloid $\beta$-protein $A \beta_{25-35}$ [19]. Apart from this, it was shown that while galanthamine (1), as desired, did not affect SH-SY5Y cell proliferation, it did protect cells from the detrimental effects of the $A \beta_{1-42}$ protein, notably those arising as a consequence of induced genomic instability [38]. The micronucleus assay showed that $A \beta_{1-42}$ exposure, in addition to causing considerable DNA damage, had a significant impact on nuclear division as gauged by the nuclear division index (NDI) [38]. Treatment with $A \beta_{1-42}$ significantly decreased the NDI but correspondingly increased some key markers linked to genomic instability such as micronuclei, nucleoplasmic bridges, and nuclear bud numbers compared to untreated controls [38]. By contrast, exposure to galanthamine caused a significant reduction in these genomic instability events [38]. These results suggested that galanthamine may be exerting its effect by regulating cell loss and prompting an antigenotoxic response [38]. It was also suggested that its antigenotoxic effect could be related to galanthamine's capacity to activate the requisite enzymes that stimulate both detoxification and DNA repair [38]. Galanthamine was also able to shield SH-SY5Y cells from the detrimental effects of both rotenone/oligomycin A and okadaic acid, as observed above [39]. From this, it was suggested that galanthamine might be acting through multitarget synergistic mechanisms to reduce the neuroinflammation and oxidative stress generated by these substances [39].

Inflammatory cells are prominent in the tumor micro-environment, which has manifold functions in the neoplastic process, particularly in cell migration, cell proliferation, and cell survival [77]. The anomalous cell proliferation levels in cancer are reciprocated by a highly aberrant and sustained immune response, as seen through cancer patients' pain and discomfort [77]. One of the key steps in the inflammatory response is the activation of phospholipase $A_{2}$, which stimulates fatty acid activity, notably that of arachidonic acid from various membrane lipids [77]. Once released, arachidonic acid is oxidized by either constitutive cyclooxygenase-1 (COX-1) or inducible cyclooxygenase-2 (COX-2) into prostanoids such as thromboxane and prostaglandins [77]. As pro-inflammatory agents, prostaglandins have key functions in inflammation-related events such as pain, fever, swelling, and tenderness [77]. Cyclooxygenase inhibition is thus a viable means of intervening in such processes [77]. Given the significant potential of the Amaryllidaceae in cancer chemotherapy, not surprisingly, 
some studies have elected to examine the COX-inhibitory effects of its alkaloid principles $[24,55,78]$. The diamine norbelladine (17) inhibited COX-1 activity by $51 \%$ and COX-2 by $25 \%$ at a relatively low concentration of $0.25 \mu \mathrm{M}$ [78]. The corresponding standards aspirin and NS-398 at equimolar concentrations reflected inhibition values of $35 \%$, respectively [78]. Also, norbelladine displayed dose-dependent DPPH-radical scavenging activity and inhibited ROS production in a cell-free xanthine/xanthine-oxidase system [78]. Since ROS is intrinsically involved with NF- $\kappa$ B activation, which in turn is closely associated with COX-2 expression, norbelladine (17) was also probed for effects on the nuclear factor $\mathrm{NF}-\kappa \mathrm{B}[78]$. To this extent, NF- $\kappa \mathrm{B}$ activity was dose-dependently inhibited by norbelladine in THP-1 leukemia cells that were stimulated by LPS treatment [78]. Overall, this suggested that norbelladine may manifest its effects via antioxidant and anti-inflammatory pathways as indicated by radical scavenging activity and COX and NF- $\kappa$ B inhibition [78]. Eight alkaloid entities were identified in the Chinese plant $L$. aurea, all of which, as indicated above, were subjected to a 7 cell line anticancer screen [24]. A scan for cyclooxygenase inhibitory activity was also carried out using the COX-1 and COX-2 enzyme substrates [24]. In the event, the bicolorine analog 1,2-dihydroxy-5,6-dihydrobicolorine (26) was over 2 times more active against COX-2 (27.6\% inhibition) than COX-1 (12.9\% inhibition) [24]. These measurements were made against the corresponding reference standards NS-398 and SC-560, which reflected substantial inhibitory values of $97.1 \%$ and $63.2 \%$, respectively [24]. Identifying several unusual cripowellin compounds $(16,73,74,75,76)$ formed the basis for studying the Chinese medicinal plant C. latifolium described above [55]. The study's biological component involved a screen for cytotoxic effects against 7 lung cancer cell lines and a probe for antioxidant and anti-inflammatory effects [55]. In the event, potent activities were detected for all 5 compounds against COX-2, where inhibitory values were $>90 \%$ relative to NS-398 (97.0\% inhibition) [55]. Although the COX-1 activities were comparatively moderate, all of the isolated compounds were more active than the reference standard SC-560 (63.5\% inhibition) [55]. In the antioxidant evaluation, all 5 compounds $(16,73,74,75,76)$ were shown to be less effective than the standard Trolox $\left(\mathrm{IC}_{50} 43.2 \mu \mathrm{M}\right)$ at radical scavenging in the DPPH assay [55]. However, compounds 74, 75, and 76 proved effective at scavenging the ABTS radical, with $\mathrm{IC}_{50}$ values in each case seen to be better than that observed for Trolox (IC $5080.9 \mu \mathrm{M})$ [55].

Apoptosis (or programmed cell death) is recognized as the chief pathway by which the cytotoxic effects of Amaryllidaceae alkaloids are manifested in cancer cells [79]. This phenomenon has been intensively examined for key representatives in the phenanthridone, lycorane, and crinane alkaloid groups of the Amaryllidaceae [79]. Although there is a paucity of information on the apoptosis-inducing effects of the family's minor alkaloid groups, some studies have addressed various aspects of this topic in recent years $[14,20,21,42,80]$. The first of these was based on the B-seco alkaloid ismine (7) ( $\bullet$ Fig. 2), as well as 4-ethyl-5,6-dihydrobicolorine (81), a synthetic analog of 5,6-dihydrobicolorine (24), which were probed for effects about Wnt/ $\beta$-catenin signaling [80]. To this extent, it was demonstrated that 4-ethyl-5,6-dihydrobicolorine (81) activated Wnt signaling in a dose- and Wnt ligand-dependent manner, none of which by comparison were observed for ismine (7) [80]. It also acted synergistically with the Wnt3a ligand to upregulate some Wnt target genes, such as Axin2, DKK1, and NKD1 [80]. A synergistic effect was also seen for 4-ethyl-5,6-dihydrobicolorine (81) together with Wnt3a to stabilize cytosolic and nuclear $\beta$-catenin [80]. These results indicated that 4-ethyl-5,6-dihydrobicolorine (81) is an activator in the Wnt/ $\beta$-catenin signaling pathway, acting upstream of $\beta$-catenin and functioning only in the presence of the Wnt3a ligand [80]. The $W n t / \beta$-catenin pathway performs several key functions in embryonic development, such as cell differentiation, cell proliferation, and cell survival [81]. It has also been linked to several human diseases, including bone disorders, Alzheimer's, and cancer [81]. It is believed that Wnt signaling could be involved in apoptosis through a variety of avenues, including SFRP2 gene expression, WntBMP signaling, GSK, 3- $\beta$-NF-KB, $\beta$-catenin activation, and JNK signaling [81]. The bicolorine-related structure zephycandidine A (77) was described following a further study of the Chinese plant Z. candida [57], which had prior yielded 15 alkaloids from its whole-plant material [17]. As noted above, it proved to be more active than cis-platin in each of the 5 cancer cell lines screened [57]. This study also involved a probe of the apoptotic effects manifested by zephycandidine A in HL-60 leukemia cells, where it exhibited its best activity $\left(\mathrm{IC}_{50} 1.98 \mu \mathrm{M}\right)$ relative to cis-platin $\left(\mathrm{IC}_{50}\right.$ $3.12 \mu \mathrm{M})$ [57]. Under inverted phase-contrast microscopy, zephycandidine A (at $3.0 \mu \mathrm{M}$ ) caused significant cell shrinkage and other abnormal morphological changes [57]. Annexin V and PI staining subsequently indicated an apoptotic incidence of $80.4 \%$ for zephycandidine A relative to etoposide phosphate (VP16) (83.8\%) [57]. Furthermore, zephycandidine A produced considerable changes in the expression of key apoptosis-related proteins, including Bax, $\mathrm{Bcl}-2$, cleaved caspase-3, and PARP as determined by Western blotting using $\beta$-actin as an internal standard [57]. Overall, the evidence suggested that zephycandidine A-induced apoptosis in leukemia cells is mediated by the activation of caspase-3, upregulation of Bax, downregulation of $\mathrm{BCl}-2$, and degradation of PARP [57]. Caspase-3 is the chief executioner protein responsible for the cleavage of several proteins, including the nuclear enzyme PARP, which, when achieved, sets into motion a cascade of events culminating with apoptotic cell death [82]. Trisphaeridine (8) and sanguinine (38) were both shown to be inactive against HepG2 and MCF7 cells, as referenced above [21]. Despite this, both compounds were also probed for caspase- 3 activation via in silico docking simulations [21]. Each showed favorable binding affinity ( -6.0 and $-6.1 \mathrm{kcal} / \mathrm{mol}$, respectively) at the active site relative to a standard tetrapeptide ligand $(-6.0 \mathrm{kcal} /$ $\mathrm{mol})$, a fragment of caspase-3 used to standardize protein-ligand binding [21]. Despite the overwhelming evidence supporting the apoptosis-inducing effects of Amaryllidaceae alkaloids [83], the fact that they are also lethal to apoptosis-resistant cells suggests that they can manifest their cytotoxicities via other pathways of cell death.

A further area explored to unravel the molecular basis of Amaryllidaceae alkaloids' cytotoxicity is their interaction with the kinase class of proteins $[13,14,47]$. Kinases are enzymes responsible for the phosphorylation of other protein molecules, an essential reaction in cellular metabolism using ATP as the phosphate 
donor [84]. It has been estimated that as much as $30 \%$ of all human proteins may be modified by kinase activity [84]. As such, they are known to mediate in most cellular pathways, particularly those involved in signal transduction such as transcription, cell cycle progression, cell differentiation, cell movement, apoptosis, cytoskeletal rearrangement, and metabolism [84]. With this as a backdrop, a library of 28 Amaryllidaceae alkaloids incorporating most structural groups of the family was examined for effects on the serine/threonine protein kinase, GSK-3 $\beta$ (glycogen synthase kinase-3 3 ) $[13,47]$. Although GSK-3 $\beta$ is most closely associated with glycogen metabolism, it has also been shown to be a promising inhibitor target in Alzheimer's disease, bipolar disorder, and stroke drug development $[13,47]$. GSK-3 $\beta$ has also garnered interest in the cancer arena, where it is believed to have a modulatory function in neoplastic transformation via Wnt/catenin and PI3K/Akt signaling [85]. All 28 Amaryllidaceae alkaloids tested were shown to be active, with inhibitory activities ranging from $10.7 \%$ to $66.0 \%[13,47]$. The minor alkaloid group representatives belladine (6) and tetrahydromasonine (82) exhibited moderate to mild inhibitory activities (34.4\% and $22.4 \%$, respectively) $[13,47]$.

Other targets probed with links to cancer include Aurora kinase A, histone deacetylase 2 (HDAC2), and vascular endothelial growth factor R2 (VEGF-R2) [14]. Although these were approached from an in silico modeling perspective, they nevertheless provided useful insight into the interaction of some Amaryllidaceae alkaloids with these interesting protein targets [14]. The study involved a structure-based virtual screening of 313 Amaryllidaceae alkaloids using the extra precision (XP) method associated with the docking program Glide to assess their suitability as ligands for the 3 targets [14]. The minor alkaloid group representative $\mathrm{N}$-formylismine (83) was rated amongst the top 10 candidates in terms of its binding affinity $(-8.41 \mathrm{kcal} / \mathrm{mol})$ for Aurora kinase A [14]. Six of the top 10 ligands predicted to have HDAC2 affinity were belladine-related compounds including, norbelladine (17) $\quad(-9.65 \mathrm{kcal} / \mathrm{mol}), \quad 4-O$-methylnorbelladine (18) $(-9.54 \mathrm{kcal} / \mathrm{mol}), 4-0, N$-dimethylnorbelladine (19) $(-10.36 \mathrm{kcal} /$ $\mathrm{mol})$, craugsodine $(84)(-9.55 \mathrm{kcal} / \mathrm{mol})$, isocraugsodine (85) $(-9.5 \mathrm{kcal} / \mathrm{mol}$,) and latisodine (86) $(-9.34 \mathrm{kcal} / \mathrm{mol})$ [14]. Ismine (7) $(-9.33 \mathrm{kcal} / \mathrm{mol})$, trisphaeridine (8) $(-10.35 \mathrm{kcal} / \mathrm{mol}), 4-0$ methylnorbelladine (18) $(-10.81 \mathrm{kcal} / \mathrm{mol}), \quad 4-O, N$-dimethylnorbelladine (19) $(-10.16 \mathrm{kcal} / \mathrm{mol}), 3,4$-dihydro-3-methoxytrisphaeridine (23) $(-10.58 \mathrm{kcal} / \mathrm{mol})$, isocraugsodine (85) $(-9.24 \mathrm{kcal} / \mathrm{mol})$, and 3-hydroxytrisphaeridine (87) (-10.71 kcal/ mol) were identified among the best candidates as ligands for VEGF-R2 [14]. By controlling chromatid segregation, Aurora kinases play a crucial role in cellular division [86]. Furthermore, any defects in chromatid segregation can produce genetic instability, a condition commonly associated with tumorigenesis [86]. Histone deacetylases are responsible for removing the acetyl group from an $\varepsilon-N$-acetyl lysine residue on a histone molecule, allowing the histone to wrap more tightly around DNA [87]. This is significant since DNA expression is regulated by both acetylation and de-acetylation reactions [87]. Although HDAC inhibitors such as valproic acid have long been associated with neurological therapeutics, the approval of vorinostat and istodax for cutaneous T-cell lymphoma has reignited interest in such molecules in the cancer arena [87]. As far as the Amaryllidaceae alkaloids are concerned, it has been shown that lycorine-mediated inhibition of HDAC is partly responsible for $G_{0} / G_{1}$ cell cycle arrest and apoptosis induction in $\mathrm{K} 562$ cells [88]. Vascular endothelial growth factor (VEGF) is a signal protein that stimulates the formation of blood vessels during both vasculogenesis and angiogenesis [89]. Since new blood vessel formation (angiogenesis) is necessary for tumor growth, invasion, and metastatic dissemination, VEGF inhibitors such as bevacizumab have come to play a pivotal role in cancer chemotherapy [89].

Further areas explored to delineate the cytotoxicity of Amaryllidaceae alkaloids relate to tyrosinase and AKR1C3 inhibition as well as effects pertaining to serotonin re-uptake $[12,20,46]$. Trisphaeridine (8), 3-methoxy-3,4-dihydrotrisphaeridine (23), and 5,6-dihydrobicolorine (24) were among the 28 compounds identified in Narcissus tazetta subsp. chinensis, a study referred to earlier in the text [20]. Tested for their abilities to inhibit theophylline-induced melanogenesis in B16 4A5 melanoma cells, all of these compounds were shown to be active, with inhibitions ranging from $14.6 \%$ to $61.7 \%$ [20]. Given the observed antimelanogenesis effects, these alkaloids were also probed for inhibitory activity towards tyrosinase, a key enzyme in melanin biosynthesis [20]. However, none of them exhibited tyrosinase-inhibitory activity using either L-tyrosine or L-DOPA as substrates, suggesting that tyrosinase inhibition is not involved in the antimelanogenesis effects of these compounds [20]. The aldo-keto reductase AKR1C3 (also referred to as $17 \beta$-hydroxysteroid dehydrogenase type 5 ) is linked to various hormone-dependent and hormone-independent cancers [12]. There is a notable elevation of AKR1C3 activity in castration-resistant prostate cancers, while modulation of its expression is known to reduce testosterone, $5 \alpha$-dihydroxytestosterone, and androgen-dependent gene expression levels [90]. Although the number of studies subjecting Amaryllidaceae alkaloids to prostate cancers is limited [79], the one above notably identified bicolorine (9) ( $\left.\mathrm{IC}_{50} 15 \mu \mathrm{M}\right)$ as more active than Z-4ethylmercaptophenylmethylene hydantoin $\left(\mathrm{IC}_{50} 37.4 \mu \mathrm{M}\right)$ against PC-3 cells [16]. Bicolorine (9) also fully inhibited (100\%) the migration of PC-3 cells in a wound healing evaluation compared to norismine (21) (38.1\%), highlighting its significance in the tumor invasion and metastasis aspects of cancer biology [16]. However, none of the minor alkaloids subsequently examined for AKR1C3 activity, including galanthamine (1), belladine (6), and tetrahydromasonine (82), were able to register inhibitory activities of $>10 \%$ relative to indomethacin ( $98 \%$ inhibition) [12]. Montanine (13) ( $\triangleright$ Fig. 3) proved to be more active than coccinine (68) in each of the 6 cell lines screened above for cytotoxic effects, including MCF7, Hs578T, MDA-MB-231, HCT-15, A549, and SKMEL-28 cells [46]. Interestingly, montanine (IC $50121.3 \mu \mathrm{M})$ had prior also proved to be better than coccinine (IC $50196.3 \mu \mathrm{M})$ at binding the serotonin transporter protein SERT, although these effects were weak relative to citalopram $\left(\mathrm{IC}_{50} 7.7 \mathrm{nM}\right)$ and paroxetine $\left(\mathrm{IC}_{50} 0.8 \mathrm{nM}\right)$ [68]. By inhibiting serotonin re-uptake, SERT is associated primarily with antidepressant effects [91]. However, there is mounting evidence suggesting that serotonin can act as a growth factor, affecting both cancer cell growth and survival [92]. Furthermore, significant levels of serotonin and 5-hydroxytryptamine (5-HT), as well as their respective synthesizing en- 
zymes tryptophan hydroxylase (TPH) 1 and 2, are observable in tissue or cancer cells extracted from cancer patients [93]. From this, it was suggested that the observed antiproliferative effects could be explained by the binding of montanine (13), and to a lesser extent, of coccinine (68), to SERT, thereby dysregulating the 5-HT system and inhibiting cancer cell growth [46].

\section{Conclusions}

Through their interesting molecular architectures and associated chemical features, the minor alkaloid groups of the Amaryllidaceae afford an abundant and diverse source of targets for anticancer-inspired drug discovery. This is reflected by the large number of such representatives that have hitherto been examined against an impressive array of cancer cells that make up around 18 different cancer types. Of the 10 alkaloid groups considered herein, most efforts have focused on the galanthamine and montanine groups. Furthermore, submicromolar level activities were detected for several representatives of these 2 groups. However, the most potent agents were identified within the obscure cripowellin group, with several of its members displaying low nanomolar cytotoxic activities. The promising results from these 3 alkaloid groups thus debunk the contemporary notion that the phenanthridone, lycorane, and crinane groups are the harbingers of the Amaryllidaceae in the cancer arena.

As a consequence of their structural diversity and the ease in which they may be transformed into a wide variety of products, the minor alkaloid groups have been deeply probed from a SAR perspective. The information gathered here, particularly for the galanthamine and montanine groups, is that in order to sustain performance, the integrity of the natural product precursor to a large extent should be maintained. Accompanying these activities were the profound insights that emerged from the mechanistic front, which showed these molecules to be responsive to several targets aligned to molecular cancer therapeutics. Since the vast majority of Amaryllidaceae species remain to be examined, going forward, studies in the phytochemical arena will no doubt boost the number of such alkaloids available for screening purposes. The re-isolation of known compounds will also facilitate the semisynthesis of a wider variety of targets designed on those that have already demonstrated promising activities. Since most of the studies described herein were from an in vitro perspective, there should be significant future interest in these alkaloids by way of animal models of study. Such studies will inevitably focus on the montanine and cripowellin groups, which have been identified as the most promising of the minor alkaloid groups of the Amaryllidaceae.

\section{Supporting Information}

Cytotoxicity data for the various constituents are provided in Tables 1S-4S as accompanying information, where they have been listed under the specific alkaloid groups.

\section{Contributors' Statement}

J. J. Nair and J. van Staden contributed at all stages of this undertaking including, design of the study, data collection, analysis and interpretation of data, as well as drafting and revision of the text.
Acknowledgements

The University of KwaZulu-Natal is thanked for the many contributions made toward the research of the authors.

Conflict of Interest

The authors declare that they have no conflict of interest.

References

[1] World Health Organization. WHO Report on Cancer. Geneva: WHO Press; 2020: 1-160

[2] Cragg GM, Pezzuto JM. Natural products as a vital source for the discovery of cancer chemotherapeutic and chemopreventive agents. Med Princ Pract 2016; 25: 41-59

[3] Bastida J, Lavilla R, Viladomat F. Chemical and biological Aspects of Narcissus Alkaloids. In: Cordell GA, ed. The Alkaloids. Amsterdam: Elsevier; 2006: 87-179

[4] Nair JJ, van Staden J. Pharmacological and toxicological insights to the South African Amaryllidaceae. Food Chem Toxicol 2013; 62: 262-275

[5] Kornienko A, Evidente A. Chemistry, biology and medicinal potential of narciclasine and its congeners. Chem Rev 2008; 108: 1982-2014

[6] Ceriotti G. Narciclasine: an antimitotic substance from Narcisssus bulbs. Nature 1967; 213: 595-596

[7] Pettit GR, Gaddamidi V, Cragg GM. Antineoplastic agents. 105. Zephyranthes grandiflora. J Nat Prod 1984; 47: 1018-1020

[8] Nair JJ, van Staden J, Bastida J. Cytotoxic Alkaloid Constituents of the Amaryllidaceae. In: Rahman A-U, ed. Studies in natural Products Chemistry. Oxford: Elsevier; 2016: 107-156

[9] Jin Z, Yao G. Amaryllidaceae and Sceletium alkaloids. Nat Prod Rep 2019; 36: $1462-1488$

[10] Kaya GI, Sarıkaya B, Onur MA, Somer NU, Viladomat F, Codina C, Bastida J, Lauinger IL, Kaiser M, Tasdemir D. Antiprotozoal alkaloids from Galanthus trojanus. Phytochem Lett 2011; 4: 301-305

[11] N'Tamon AD, Okpekon AT, Bony NF, Bernadat G, Gallard JF, Kouamé T, Séon-Méniel B, Leblanc K, Rharrabti S, Mouray E, Grellier P, Ake M, Amin NC, Champy P, Beniddir MA, Le Pogam P. Streamlined targeting of Amaryllidaceae alkaloids from the bulbs of Crinum scillifolium using spectrometric and taxonomically-informed scoring metabolite annotations. Phytochemistry 2020; 179: 112485/1-112485/8

[12] Hulcova D, Breiterova K, Zemanova L, Siatka T, Safratova M, Vaneckova N, Hostalkova A, Wsol V, Cahlikova L. AKR1C3 inhibitory potency of naturally-occurring Amaryllidaceae alkaloids of different structural types. Nat Prod Commun 2017; 12: 245-246

[13] Hulcova D, Breiterova K, Siatka T, Klimova K, Davani L, Safratova M, Hostalkova A, de Simone A, Andrisano V, Cahlikova L. Amaryllidaceae alkaloids as potential glycogen synthase kinase- $3 \beta$ inhibitors. Molecules 2018; 23: 719/1-719/9

[14] Shawky E. In-silico profiling of the biological activities of Amaryllidaceae alkaloids. J Pharm Pharmacol 2017; 69: 1592-1605

[15] Zupko I, Rethey B, Hohmann J, Molnar J, Ocsovski I, Falkay G. Antitumor activity of alkaloids derived from Amaryllidaceae species. In Vivo 2009; 23: $41-48$

[16] Ibrahim SRM, Mohamed GA, Shaala LA, Youssef DTA, El Sayed KA. New alkaloids from Pancratium maritimum. Planta Med 2013; 79: 1480 1484

[17] Luo Z, Wang F, Zhang J, Li X, Zhang M, Hao X, Xue Y, Li Y, Horgen FD, Yao $\mathrm{G}$, Zhang Y. Cytotoxic alkaloids from the whole plants of Zephyranthes candida. J Nat Prod 2012; 75: 2113-2120 
[18] Ang S, Liu XM, Huang X], Zhang DM, Zhang W, Wang L, Ye WC. Four new Amaryllidaceae alkaloids from Lycoris radiata and their cytotoxicity. Planta Med 2015; 81: 1712-1718

[19] Zhu YY, Li X, Yu HY, Xiong YF, Zhang P, Pi HF, Ruan HL. Alkaloids from the bulbs of Lycoris longituba and their neuroprotective and acetylcholinesterase inhibitory activities. Arch Pharm Res 2015; 38: 604-613

[20] Morikawa T, Ninomiya K, Kuramoto H, Kamei I, Yoshikawa M, Muraoka O. Phenylethanoid and phenylpropanoid glycosides with melanogenesis inhibitory activity from the flowers of Narcissus tazetta var. chinensis. J Nat Med 2016; 70: 89-101

[21] Cole ER, de Andrade JP, Filho JFA, Schmitt EFP, Alves-Araujo A, Bastida J, Endringer DC, de Souza Borges W, Lacerda V jr. Cytotoxic and genotoxic activities of alkaloids from the bulbs of Griffinia gardneriana and Habranthus itaobinus (Amaryllidaceae). Anticancer Agents Med Chem 2019; 19: 707-717

[22] Weniger B, Italiano L, Beck JP, Bastida J, Bergoñon S, Codina C, Lobstein A, Anton R. Cytotoxic activity of Amaryllidaceae alkaloids. Planta Med 1995; 61: 77-79

[23] Hao B, Shen SF, Zhao Q]. Cytotoxic and antimalarial alkaloids from the bulbs of Lycoris radiata. Molecules 2013; 18: 2458-2468

[24] Song JH, Zhang L, Song Y. Alkaloids from Lycoris aurea and their cytotoxicities against the head and neck squamous cell carcinoma. Fitoterapia 2014; 95: 121-126

[25] Ka S, Masi M, Merindol N, Di Lecce R, Plourde MB, Seck M, Gorecki M, Pescitelli G, Desgagne-Penix I, Evidente A. Gigantelline, gigantellinine and gigancrinine, cherylline- and crinine-type alkaloids isolated from Crinum jagus with anti-acetylcholinesterase activity. Phytochemistry 2020; 175: $112390 / 1-112390 / 9$

[26] Heinrich M. Galanthamine from Galanthus and other Amaryllidaceae Chemistry and Biology based on traditional Use. In: Cordell GA, ed. The Alkaloids. Chennai: Academic Press; 2010: 157-165

[27] Jimenez A, Santos A, Alonso G, Vazquez D. Inhibitors of protein synthesis in eukaryotic cells. Comparative effects of some Amaryllidaceae alkaloids. Biochim Biophys Acta 1976; 425: 342-348

[28] Furusawa E, Irie H, Combs D, Wildman WC. Therapeutic activity of pretazettine on Rauscher leukemia: comparison with the related Amaryllidaceae alkaloids. Chemotherapy 1980; 26: 36-45

[29] Nair J], Rárová L, Strnad M, Bastida J, van Staden J. Apoptosis-inducing effects of distichamine and narciprimine, rare alkaloids of the plant family Amaryllidaceae. Bioorg Med Chem Lett 2012; 22: 6195-6199

[30] Ezoulin MJM, Dong CZ, Liu Z, Li J, Chen HZ, Heymans F, Lelievre L, Ombetta JE, Massicot F. Study of PMS777, a new type of acetylcholinesterase inhibitor, in human HepG2 cells. Comparison with tacrine and galanthamine on oxidative stress and mitochondrial impairment. Toxicol In Vitro 2006; 20: 824-831

[31] Breiterova K, Koutova D, Marikova J, Havelek R, Kunes J, Majorosova M, Opletal L, Hostalkova A, Jenco J, Rezacova M, Cahlikova L. Amaryllidaceae alkaloids of different structural types from Narcissus L. Cv. Professor Einstein and their cytotoxic activity. Plants 2020; 9: 137/1-137/12

[32] Osorio E], Berkov S, Brun R, Codina C, Viladomat F, Cabezas F, Bastida J. In vitro antiprotozoal activity of alkaloids from Phaedranassa dubia (Amaryllidaceae). Phytochem Lett 2010; 3: 161-163

[33] Doskocil I, Hostalkova A, Safratova M, Benesova N, Havlik J, Havelek R, Kunes J, Kralovec K, Chlebek J, Cahlikova L. Cytotoxic activities of Amaryllidaceae alkaloids against gastrointestinal cancer cells. Phytochem Lett 2015; 13: 394-398

[34] Havelek R, Muthna D, Tomsik P, Kralovec K, Seifrtova M, Cahlikova L, Hostalkova A, Safratova M, Perwein M, Cermakova E, Rezacova M. Anticancer potential of Amaryllidaceae alkaloids evaluated by screening with a panel of human cells, real-time cellular analysis and Ehrlich tumorbearing mice. Chem Biol Interact 2017; 275: 121-132

[35] Carvalho KR, Silva AB, Torres MCM, Pinto FCL, Guimaraes LA, Rocha DD, Silveira ER, Costa-Lotufo LV, Braz-Filho R, Pessoa ODL. Cytotoxic alkaloids from Hippeastrum solandriflorum Lindl. J Braz Chem Soc 2015; 26: 1976 1980

[36] Jitsuno M, Yokosuka A, Hashimoto K, Amano O, Sakagami H, Mimaki Y. Chemical constituents of Lycoris albiflora and their cytotoxic activities. Nat Prod Commun 2011; 6: 187-192

[37] Jin A, Li X, Zhu YY, Yu HY, Pi HF, Zhang P, Ruan HL. Four new compounds from the bulbs of Lycoris aurea with neuroprotective effects against $\mathrm{CoCl}_{2}$ and $\mathrm{H}_{2} \mathrm{O}_{2}$-induced SH-SY5Y cell injuries. Arch Pharm Res 2014; 37: 315-323

[38] Castillo WO, Aristizabal-Pachon AF, de Lima Montaldi AP, Sakamoto-Hojo ET, Takahashi CS. Galanthamine decreases genotoxicity and cell death induced by $\beta$-amyloid peptide in SH-SY5Y cell line. Neurotoxicology 2016; 57: 291-297

[39] Trujillo-Chacon LM, Alarcon-Enos JE, Cespedes-Acuna CL, Bustamante L, Baeza M, Lopez MG, Fernandez-Mendivil C, Cabezas F, Pastene-Navarrete ER. Neuroprotective activity of isoquinoline alkaloids from of Chilean Amaryllidaceae plants against oxidative stress-induced cytotoxicity on human neuroblastoma SH-SY5Y cells and mouse hippocampal slice culture. Food Chem Toxicol 2019; 132: 110665/1-110665/11

[40] Labrana ], Machocho AK, Kricsfalusy V, Brun R, Codina C, Viladomat F, Bastida J. Alkaloids from Narcissus angustifolius subsp. transcarpathicus (Amaryllidaceae). Phytochemistry 2002; 60: 847-852

[41] Cedron JC, Ravelo AG, Leon LG, Padron JM, Estevez-Braun A. Antiproliferative and structure activity relationships of Amaryllidaceae alkaloids. Molecules 2015; 20: 13854-13863

[42] Govindaraju K, Ingels A, Hasan MN, Sun D, Mathieu V, Masi M, Evidente A, Kornienko A. Synthetic analogues of the montanine-type alkaloids with activity against apoptosis-resistant cancer cells. Bioorg Med Chem Lett 2018; 28: 589-593

[43] Silva AFS, de Andrade JP, Machado KRB, Rocha AB, Apel MA, Sobral MEG Henriques AT, Zuanazzi JAS. Screening for cytotoxic activity of extracts and isolated alkaloids from bulbs of Hippeastrum vittatum. Phytomedicine 2008; 15: 882-885

[44] Al Shammari L, Al Mamun A, Koutová D, Majorošová M, Hulcová D, Šafratová M, Breiterová K, Maříková J, Havelek R, Cahlíková L. Alkaloid profiling of Hippeastrum cultivars by GC-MS, isolation of Amaryllidaceae alkaloids and evaluation of their cytotoxicity. Rec Nat Prod 2020; 14 : 154-159

[45] Wu WM, Zhu YY, Li HR, Yu HY, Zhang P, Pi HF, Ruan HL. Two new alkaloids from the bulbs of Lycoris sprengeri. J Asian Nat Prod Res 2014; 16 : 192-199

[46] Masi M, van Slambrouck S, Gunawardana S, van Rensburg M], James PC, Mochel JG, Heliso PS, Albalawi AS, Cimmino A, van Otterlo WAL, Kornienko A, Green IR, Evidente A. Alkaloids isolated from Haemanthus humilis Jacq., an indigenous South African Amaryllidaceae: anticancer activity of coccinine and montanine. S Afr J Bot 2019; 126: 277-281

[47] Hulcova D, Marikova J, Korabecny J, Hostalkova A, Jun D, Kunes J, Chlebek J, Opletal L, de Simone A, Novakova L, Andrisano V, Ruzicka A, Cahlikova L. Amaryllidaceae alkaloids from Narcissus pseudonarcissus L. cv. Dutch Master as potential drugs in treatment of Alzheimer's disease. Phytochemistry 2019; 165: 112055/1-112055/9

[48] Ali AA, Hambloch H, Frahm AW. Alkaloids of Crinum augustum. Part 4. Relative configuration of the alkaloid augustamine. Phytochemistry 1983; 22: 283-287

[49] Machocho AK, Bastida J, Codina C, Viladomat F, Brun R, Chhabra SC. Augustamine-type alkaloids from Crinum kirkii. Phytochemistry 2004; 65: 3143-3149

[50] Hanh TTH, Anh DH, Huong PTT, Nguyen VT, Nguyen QT, Cuong TV, Nguyen TM, Nguyen TC, Nguyen XC, Nguyen HN, Minh CV. Crinane, augustamine, and $\beta$-carboline alkaloids from Crinum latifolium. Phytochem Lett $2018 ; 24: 27-30$

[51] Tallini LR, Torras-Claveria L, de Souza Borges W, Kaiser M, Viladomat F, Zuanazzi JAS, Bastida J. N-oxide alkaloids from Crinum amabile (Amaryllidaceae). Molecules 2018; 23: 1277/1-1277/11 
[52] Hafiz AMA, Ramadan MA, Jung ML, Beck JP, Anton R. Cytotoxic activity of Amaryllidaceae alkaloids from Crinum augustum and Crinum bulbispermum. Planta Med 1991; 57: 437-439

[53] Velten R, Erdelen C, Gehling M, Gohrt A, Gondol D, Lenz J, Lockhoff O, Wachendorff U, Wendisch D. Cripowellin A and B, a novel type of Amaryllidaceae alkaloid from Crinum powellii. Tet Lett 1998; 39: 1737-1740

[54] Presley CC, Krai P, Dalal S, Su Q, Cassera M, Goetz M, Kingston DGI. New potently bioactive alkaloids from Crinum erubescens. Bioorg Med Chem 2016; 24: 5418-5422

[55] Chen MX, Huo JM, Hu J, Xu ZP, Zhang X. Amaryllidaceae alkaloids from Crinum latifolium with cytotoxic, antimicrobial, antioxidant and antiinflammatory activities. Fitoterapia 2018; 130: 48-53

[56] Tram NTM, Titorenkova TV, Bankova VS, Handjieva NV, Popov SS. Crinum L. (Amaryllidaceae); a review. Fitoterapia 2002; 73: 183-208

[57] Zhan G, Qu X, Liu J, Tong Q, Zhou J, Sun B, Yao G. Zephycandidine A, the first naturally occurring imidazo[1,2-f. phenanthridine alkaloid from Zephyranthes candida, exhibits significant anti-tumor and antiacetylcholinesterase activities. Sci Rep 2016; 6: 33990/1-33990/9

[58] Nair JJ, van Staden J. Cytotoxic tazettine alkaloids of the plant family Amaryllidaceae. S Afr J Bot 2021; 136: 147-156

[59] Nair J], van Staden J. The plant family Amaryllidaceae as a source of cytotoxic homolycorine alkaloid principles. S Afr J Bot 2021; 136: 157-174

[60] Schmeda-Hirschmann G, Astudillo L, Bastida J, Viladomat F, Codina C. DNA binding activity of Amaryllidaceae alkaloids. J Chil Chem Soc 2000; 45: $515-518$

[61] Hohmann J, Forgo P, Molnár J, Wolfard K, Molnár A, Thalhammer T, Mathé I, Sharples D. Antiproliferative Amaryllidaceae alkaloids isolated from the bulbs of Sprekelia formosissima and Hymenocallis $x$ festalis. Planta Med 2002; 68: 454-457

[62] Ingrassia L, Lefranc F, Dewelle J, Pottier L, Mathieu V, Spiegl-Kreinecker S, Sauvage S, El Yazidi M, Dehoux M, Berger W, van Quaquebeke E, Kiss R. Structure-activity relationship analysis of novel derivatives of narciclasine (an Amaryllidaceae isocarbostyril derivative) as potential anticancer agents. J Med Chem 2009; 52: 1100-1114

[63] Lefranc F, Sauvage S, van Goietsenoven G, Mégalizzi V, Lamoral-Theys D, Debeir O, Spiegl-Kreinecker S, Berger W, Mathieu V, Decaestecker C, Kiss R. Narciclasine, a plant growth modulator, activates Rho and stress fibers in glioblastoma cells. Mol Cancer Ther 2009; 8: 1739-1750

[64] Antonicek HP, Velten R, Jeschke P. Cripowellins and synthetic derivatives thereof used as medicaments. European Patent WO2006136309A1; 2006

[65] McNulty J, Nair J], Singh M, Crankshaw DJ, Holloway AC, Bastida J. Selective cytochrome P450 3A4 inhibitory activity of Amaryllidaceae alkaloids. Bioorg Med Chem Lett 2009; 19: 3233-3237

[66] Rendic S, Di Carlo FJ. Human cytochrome P450 enzymes: a status report summarizing their reactions, substrates, inducers and inhibitors. Drug Metab Rev 1997; 29: 413-580

[67] Sharom F]. The P-glycoprotein multidrug transporter. Essays Biochem 2011; 50: 161-178

[68] Stafford GI, Birer C, Brodin B, Christensen SB, Eriksson AH, Jäger AK, Rønsted N. Serotonin transporter protein (SERT) and P-glycoprotein (P-gp) binding activity of montanine and coccinine from three species of Haemanthus L. (Amaryllidaceae). S Afr J Bot 2013; 88: 101-106

[69] Abdel-Halim OB, Morikawa T, Ando S, Matsuda H, Yoshikawa M. New crinine-type alkaloids with inhibitory effect on induction of inducible nitric oxide synthase from Crinum yemense. J Nat Prod 2004; 67: 1119-1124

[70] Xu W, Liu LZ, Loizidou M, Ahmed M, Charles IG. The role of nitric oxide in cancer. Cell Res 2002; 12: 311-320

[71] Champoux J]. DNA topoisomerases: structure, function and mechanism. Annu Rev Biochem 2001; 70: 369-413

[72] Sarıkaya BB, Zencir S, Somer NU, Kaya GI, Onur MA, Bastida J, Berenyi A, Zupko I, Topcu Z. The effects of arolycoricidine and narciprimine on tu- mor cell killing and topoisomerase activity. Rec Nat Prod 2012; 6: 381 385

[73] Nino ], Hincapié GM, Correa YM, Mosquera OM. Alkaloids of Crinum x powellii "Album" (Amaryllidaceae) and their topoisomerase inhibitory activity. Z Naturforsch 2007; 62c: 223-226

[74] Evidente A, Kireev AS, Jenkins AR, Romero AE, Steelant WFA, van Slambrouck S, Kornienko A. Biological evaluation of structurally diverse Amaryllidaceae alkaloids and their synthetic derivatives: discovery of novel leads for anticancer drug design. Planta Med 2009; 75: 501-507

[75] Stock AM, Troost G, Niggemann B, Zänker KS, Entschladen F. Targets for anti-metastatic drug development. Curr Pharm Des 2013; 19: 51275134

[76] Kovalevich J, Langford D. Considerations for the use of SH-SY5Y neuroblastoma cells in neurobiology. Methods Mol Biol 2013; 1078: 9-21

[77] Coussens LM, Werb Z. Inflammation and cancer. Nature 2002; 420: 860867

[78] Park JB. Synthesis and characterization of norbelladine, a precursor of Amaryllidaceae alkaloid, as an anti-inflammatory/anti-COX compound. Bioorg Med Chem Lett 2014; 24: 5381-5384

[79] Nair JJ, van Staden J, Bastida J. Apoptosis-inducing effects of Amaryllidaceae alkaloids. Curr Med Chem 2016; 23: 161-185

[80] Wang S, Yin J, Chen D, Nie F, Song X, Fei C, Miao H, Jing C, Ma W, Wang L, Xie S, Li C, Zeng R, Pan W, Hao X, Li L. Small-molecule modulation of Wnt signaling via modulating the Axin-LRP5/6 interaction. Nat Chem Biol 2013; 9: 579-585

[81] Clevers H, Nusse R. Wnt/ $\beta$-catenin signaling and disease. Cell 2012; 149: 1192-1205

[82] Cohen GM. Caspases: the executioners of apoptosis. Biochem J 1997; 326: 1-16

[83] Van Goietsenoven G, Andolfi A, Lallemand B, Cimmino A, Lamoral-Theys D, Gras T, Abou-Donia A, Dubois J, Lefranc F, Mathieu V, Kornienko A, Kiss R, Evidente A. Amaryllidaceae alkaloids belonging to different structural subgroups display activity against apoptosis-resistant cancer cells. J Nat Prod 2010; 73: 1223-1227

[84] Manning G, Whyte DB, Martinez R, Hunter T, Sudarsanam S. The protein kinase complement of the human genome. Science 2002; 298: 1912 1934

[85] Luo J. Glycogen synthase kinase 3b (GSK3b) in tumorigenesis and cancer chemotherapy. Cancer Lett 2009; 273: 194-200

[86] Bolanos-Garcia VM. Aurora kinases. Int J Biochem Cell Biol 2005; 37: 1572-1577

[87] Milazzo G, Mercatelli D, Di Muzio G, Triboli L, De Rosa P, Perini G Giorgi FM. Histone deacetylases (HDACs): evolution, specificity, role in transcriptional complexes, and pharmacological actionability. Genes (Basel) 2020; 11: 556/1-556/49

[88] Li L, Dai HJ, Ye M, Wang SL, Xiao XJ, Zheng J, Chen HY, Luo YH, Liu J Lycorine induces cell cycle arrest in the $\mathrm{G}_{0} / \mathrm{G}_{1}$ phase in $\mathrm{K} 562$ cells via HDAC inhibition. Cancer Cell Int 2012; 12: 49-54

[89] Holmes DIR, Zachary I. The vascular endothelial growth factor (VEGF) family: angiogenic factors in health and disease. Genome Biol 2005; 6: 209/1-209/10

[90] Penning TM, Byrns MC. Steroid hormone transforming aldo-keto reductases and cancer. Ann N Y Acad Sci 2009; 1155: 33-42

[91] Stahl SM. Mechanism of action of serotonin selective reuptake inhibitors: serotonin receptors and pathways mediate therapeutic effects and side effects. J Affect Disord 1998; 51: 215-235

[92] Sarrouilhe D, Mesnil M. Serotonin and human cancer: a critical view. Biochimie 2019; 161: 46-50

[93] Shinka T, Onodera D, Tanaka T, Miyazaki T, Moriuchi T, Fukumoto T. Serotonin synthesis and metabolism-related molecules in a human prostate cancer cell line. Oncol Lett 2011; 2: 211-215 